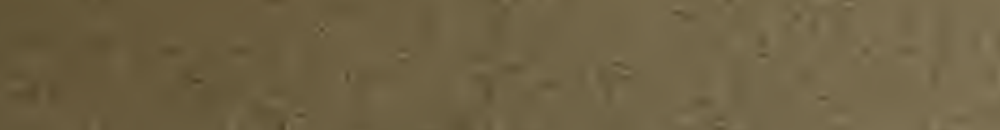

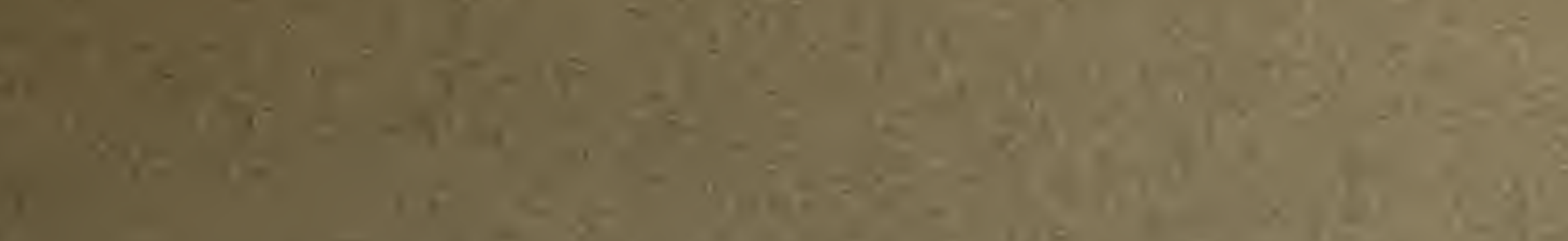

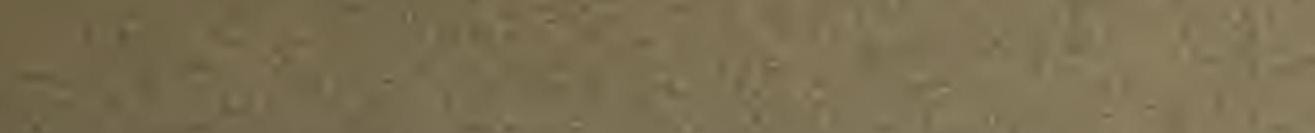

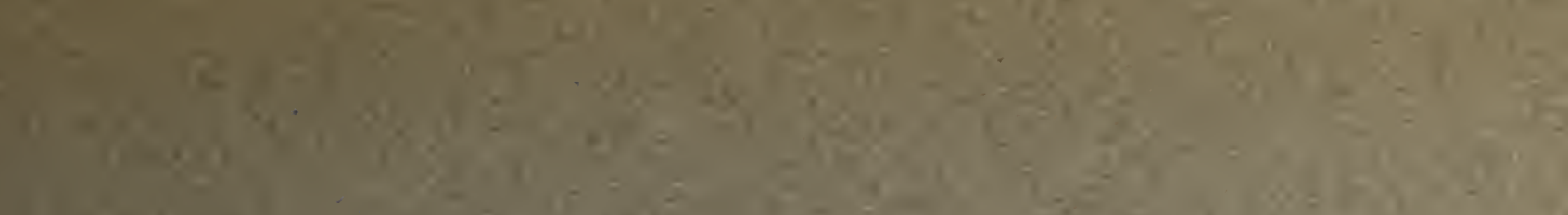

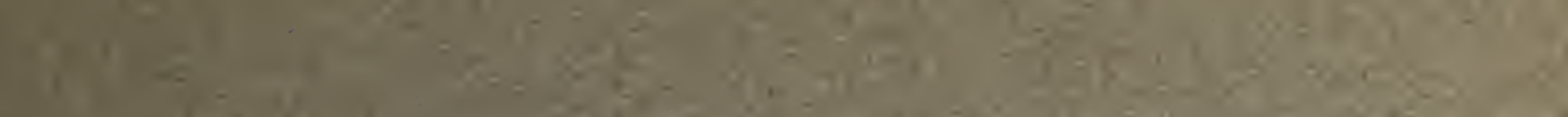

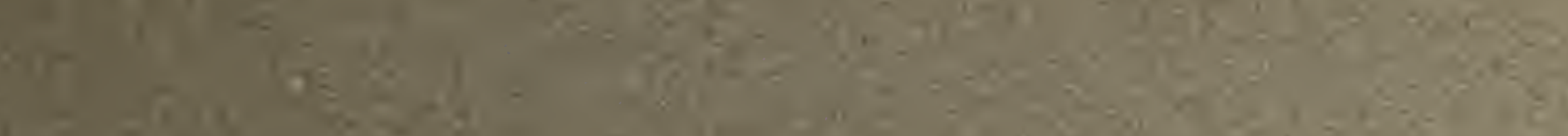

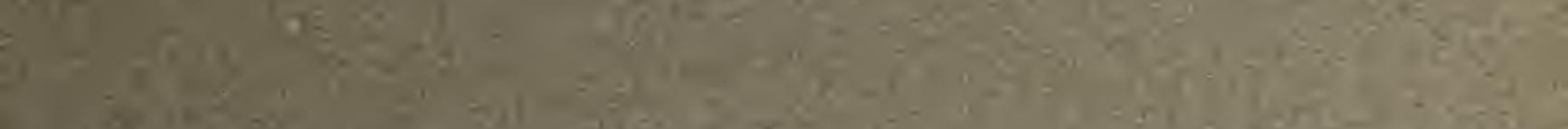

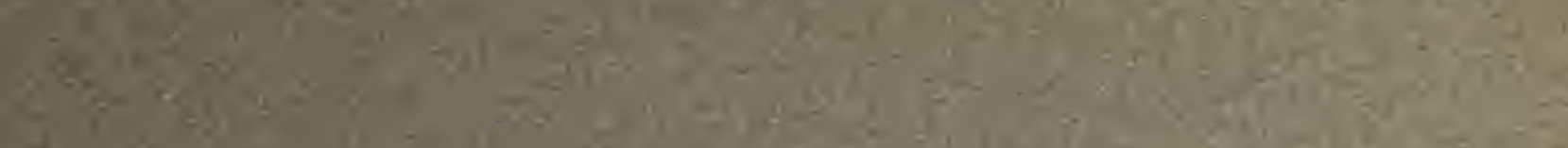
Gr.

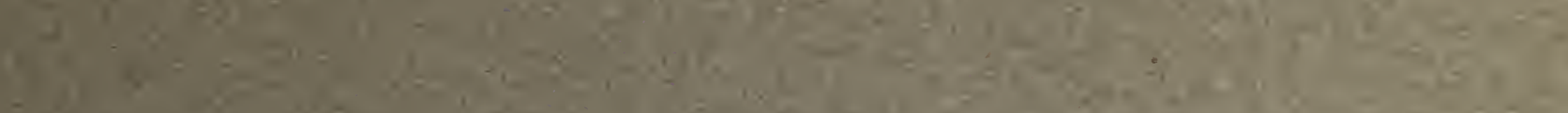

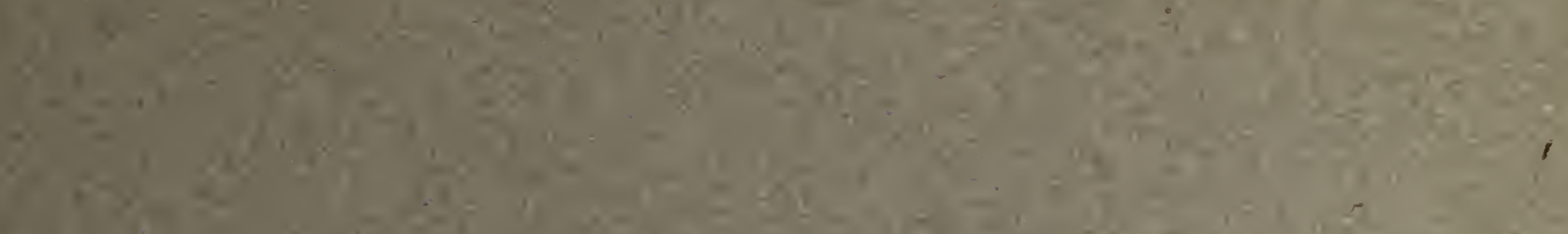

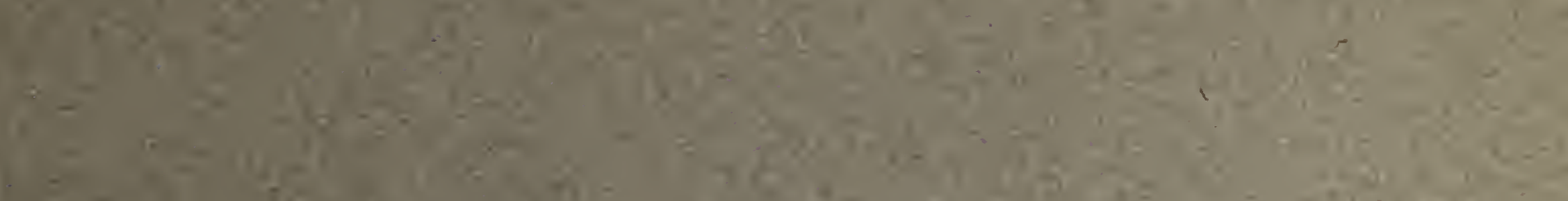

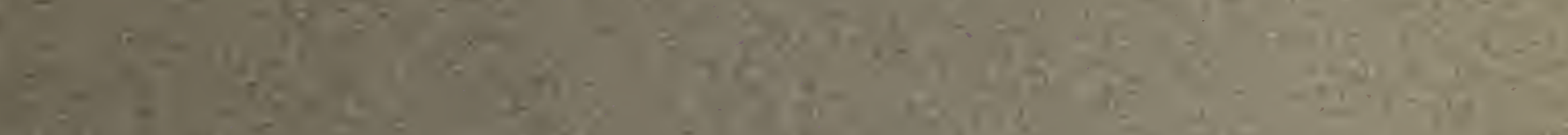

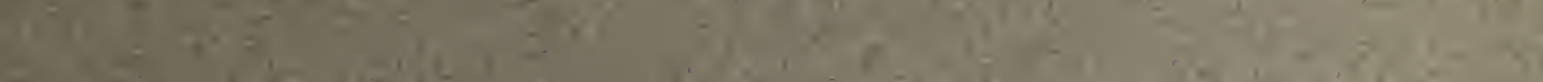

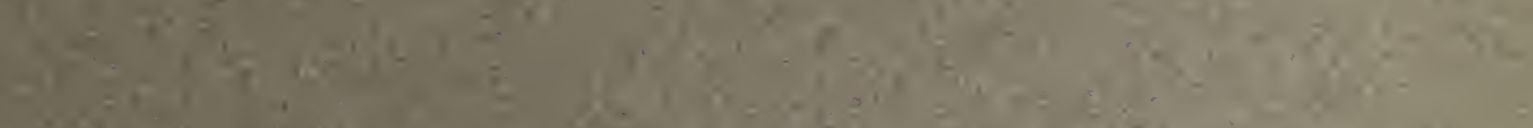

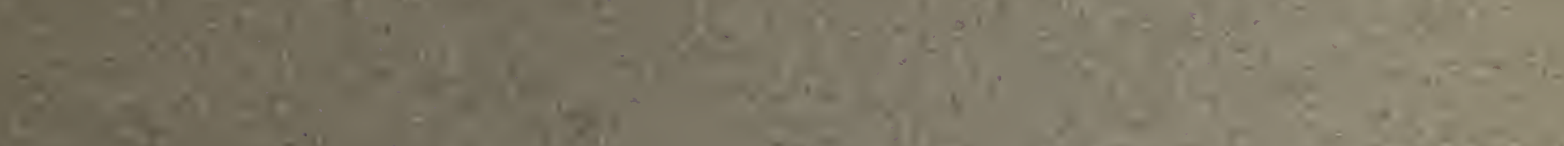

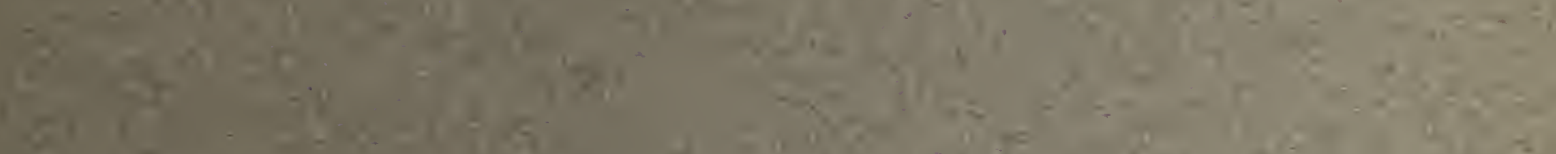

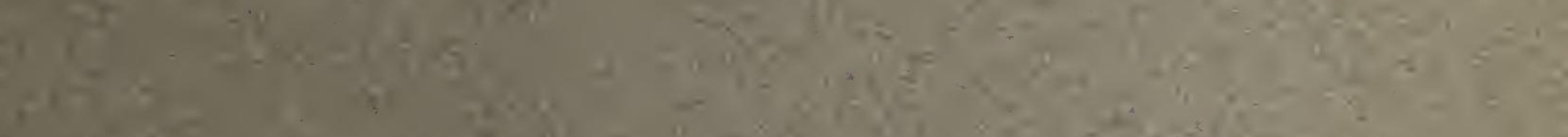

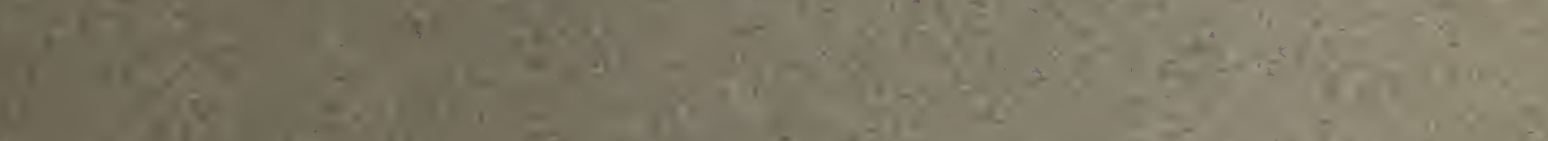

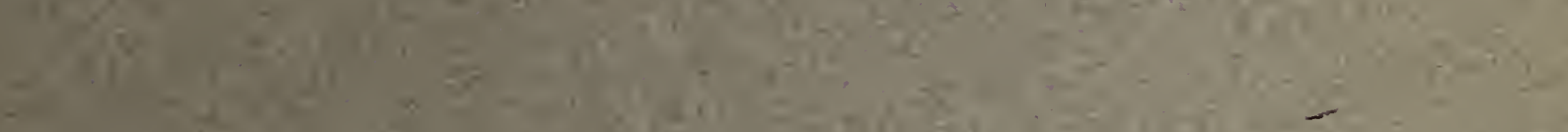

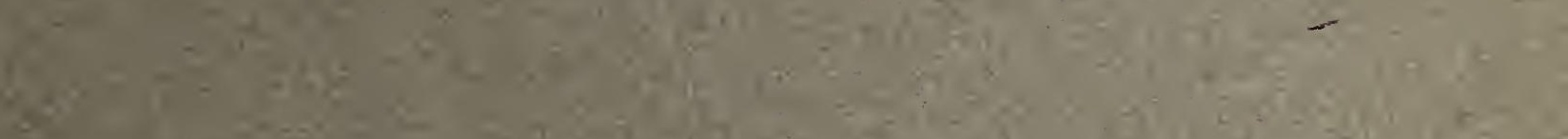

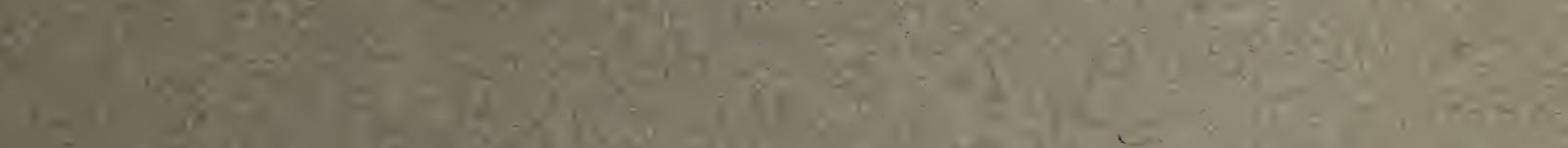

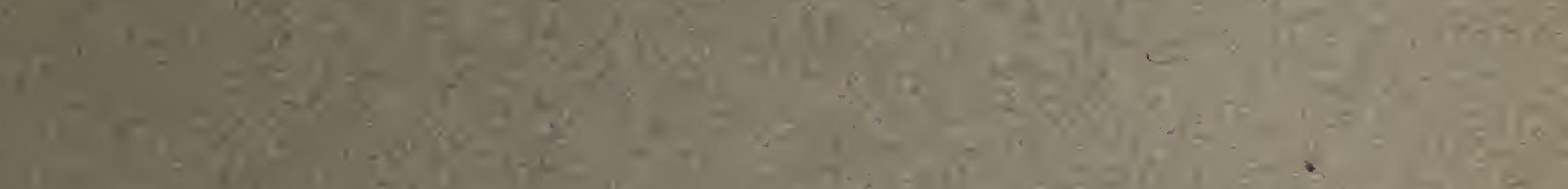

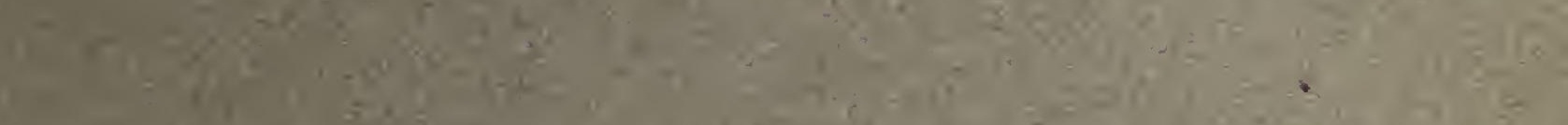

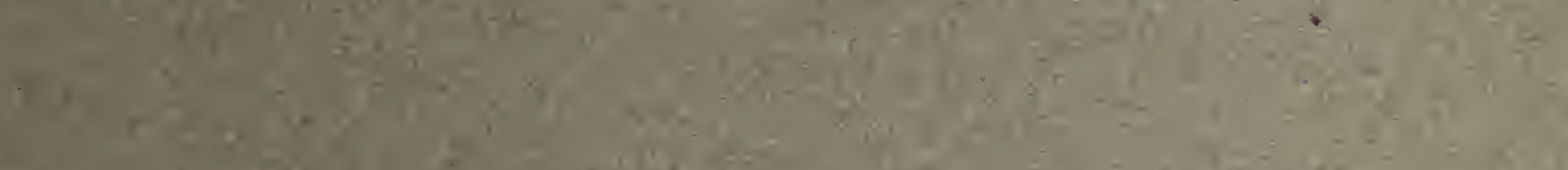

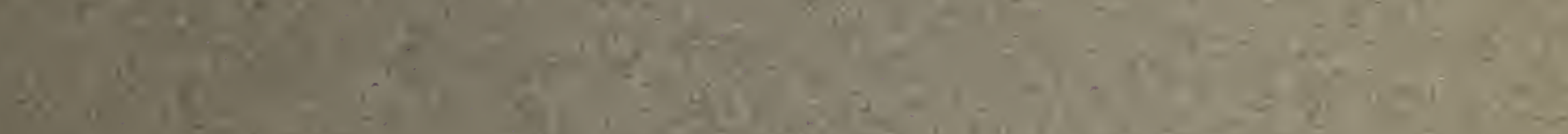

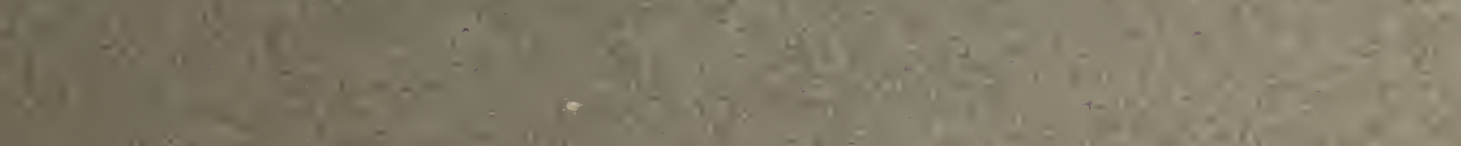

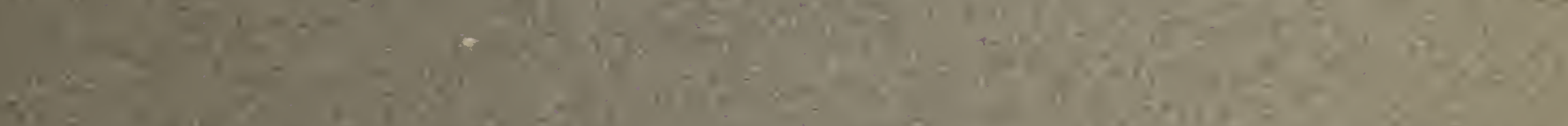

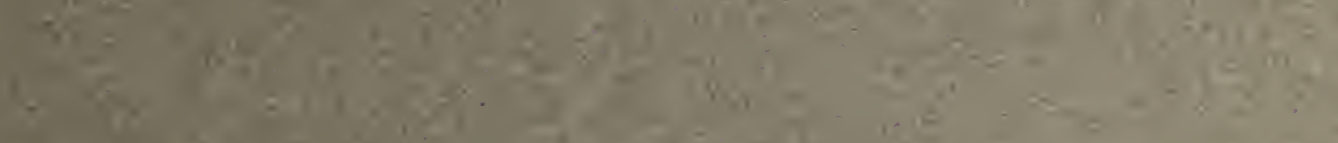

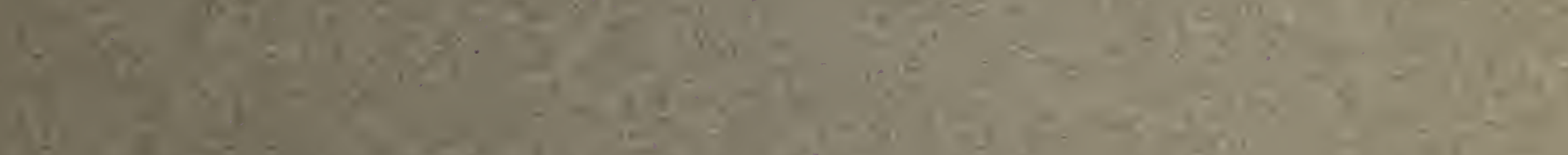

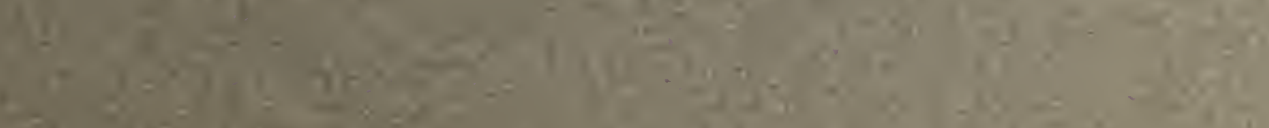

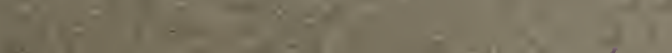

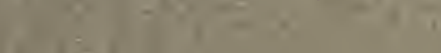


HARVARD UNIVERSITY.

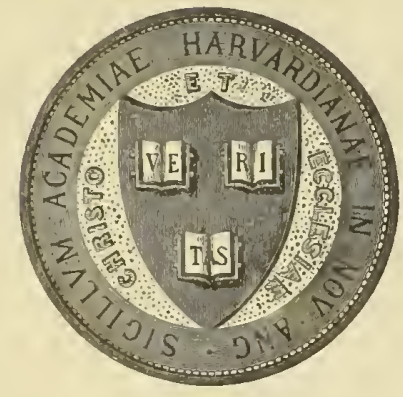

LIBRARY

OF THE

MUSEUM OF COMPARATIVE ZOÖLOGY

$$
64,98^{\circ}
$$

Peabodymusum

Ciprel 3. 1925 


\section{APR 3 192:}

64,987

Красноярскій Подъотдьлъ И. Р. Географическаго Общества.

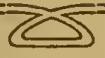

\section{ОПИСАНIE}

\section{KOIIERLIЙ KPACHOЯPCКAГГО MYЗЕЯ}

Отдђль папеонтопогическій.

ВЫПУСКъ 1-й.

A. Собопевъ.

ПОСЛ БТРЕТИЧНЫЯ МЛЕКОПИТАЮЩІЯ.

1. Коп ы т ны я.

ค. $О$ ก е ни.

-(Съ 3 таблицамн).

КРАСНОЯРСКЪ.

Типографія, б. М. И. Абалакова.

1914. 
Печатано по постановленію Распорядительнаго Комитета Красноярск. Подъотдъла Императорскато Русскаго Географическаго Общества.

За Правителя дъль A. Тугариновъ. 
Der Krasnojarskische Abteil der KAIS. Russ. Geograph. Gesellschaft.

\section{BESCHREIBUNG DER SAMMLUNGEN}

\section{DES MUSEUMS IN KRASNOJARSK.}

PALÄONTOLOGISCHER TEIL.

Lieferung !.

A. Sobolew.

Posttertiäre Säugethiere.

1. Hufthiere.

A. Elenthiere.

(Mit 3 Tafeln). 
Красноярскій Подъотдђпь ИМП. Русск. Географическаго Общества.

\section{ОПИСАНIE KОПЛЕКЧIЙ}

\section{КРАСНОЯРСКАГО МУЗЕЯ.}

О'ТДҢЛ' ПАЈЕОН'ТОЛОГИЧЕСКІЙ.

Bыпускъ I.

А. Собопевъ.

Поспьтретичныя мпекопитающія.

1. Копытныя.

Я. Опени.

( $\mathrm{C}_{\text {ъ }} 3$ тао̆л.). 



\section{Отъ автора.}

Іереданная мнђ для опреджленія полтекція гостей пскопаемыхт оленей яв.яется частью оощей палеонтологиеской коллекцін Красноярскаго музея, пропсходяцей капт пзъ окрестностей Красноярска, такт, п изъ разлпныхт, мњстностей Енисейской гуó. Считаю необходимым указать здъсь на тотт, порядокъ, котораго

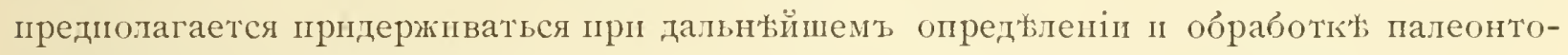
логиеской коллекцін музея.

Іа:теонтлогическіе матеріалы предстантены гл. обр. четвертиными позвоноч-

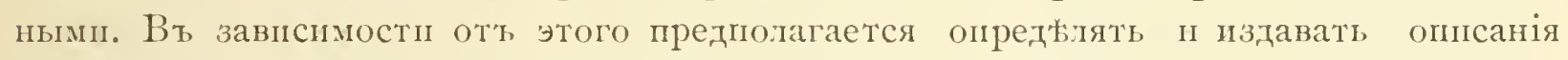
колтекцій приблизтельно вт такомт порядкь: г) оленевыя, 2) полорогія, 3) непарнопалыя, 4) хоботныя, 5) хищцыя п 6) грызуны и насккомоядныя.

Само собой разуметси, что иногда прпдется соединять описаніе нъготорыхъ подклассовъ животныхъ еъ одномъ выпскљ, всльдствіе, напр., недостаточности матеріала по кажгому пзъ пихь въ отдилности, плп, напр., потому, тто часть коллекціи, относящаяся къ одному отряду, будетъ заназдывать выходомт сравнительно съ другой частью колекціп по тому же отряду, всльдствіе просто болже поздняго поступленія этой тасти въ музей пли для опредыленія.

Считаю свопмъ пріятнымъ долгомь прннесті искреннюю благодарность г-жъ M. В. Павловой за любезную помоць, выразивпуюся вт, провжркж моихт, опреджленій и совьтахь, касающихся настоящей работы.

Москва. Палеонтологическії кабинеть городск.

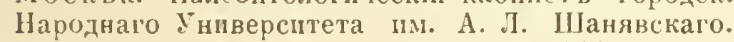

Декабрь, $1913 \mathrm{r}$. 



\section{CERVIDAE.}

\section{6 щ}

Семейство оленевыхъ (не полорогихъ), Cervidae (изљ отр. Selenodonta- жвачныя подкласса Artiodactyla парнопалыя), отличается костяными разнообразно вьтвящилися рогами, періодически спадающими въ розеткъ. Смжна роговъ происходить ежегодно, при чем'ь на вновь выростающихъ рогахъ подмжнается та особенность, что ежегодно же прибавляется по одному лишнему отвњтвленію, отростку. Рога приростають на незначительныхъ выростахъ лобныхь костей. Подобныхъ выростовъ побныхъ костей у нъкоторыхь вндовъ оленей не бываеть, и тогда рога приростаютьь

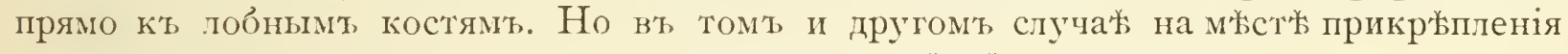
рога развивается такъ наз. розетка, опадающая вмъсть съ рогомъ.

IІоловое различіе особей въ этомъ отношеніи заклюгается въ томъ, что у большнства видовъ оленей самки совсъмъ лишены роговъ, или снабжены менъе развитыми.

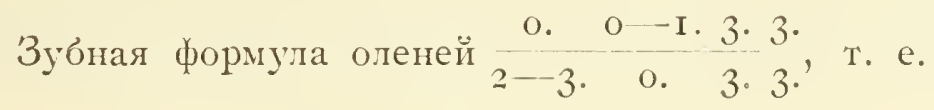

вверху н安ть совершенно ржзцовъ и клыковъ. Посльднихъ ньть совершенно въ нижней челюсти. Вообще же ужначныхъ клыкь сохраняется очень рыдко и только у самцовъ.

\section{Cervus tarandus fossilis $0 w$.}

Этому виду принадлежить большинство остатковъ коллекціи. Область распространенія съвернаго оленя простиралась значительно южнће, чьъм въ настоящее время. *) Больпая часть пскопаемыхъ остатковъ этого вида является обломками роговъ, которые имжются у обоихъ половъ, главншмъ образомъ обломками съ розеткой и первымт отросткомъ.

*) Распространеніе дикаго съвернаго оленя въ настоищее время представлиетсл въ сльдующемъ видъ.

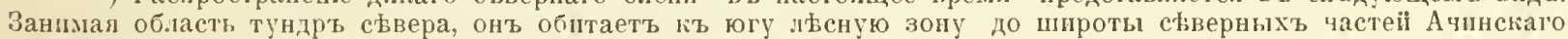

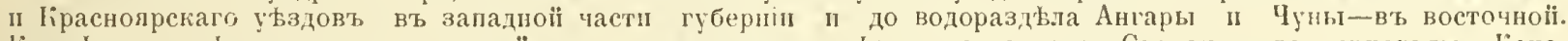

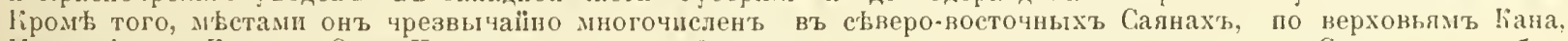
Маны, Агула, Казыра, Ои и Уса, обитал какъ сњверные. тықъ и южные склоны главнаго Саянекаго хребта. Къ западу отъ Енисея въ пред'вахъ Салнъ-не пзвьстенъ. 


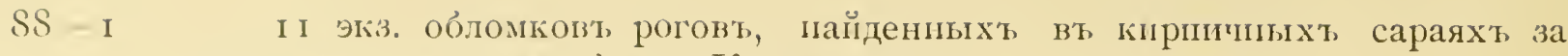
военйлт, городкомт, близт, Красиоярска.

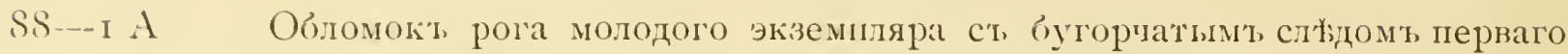

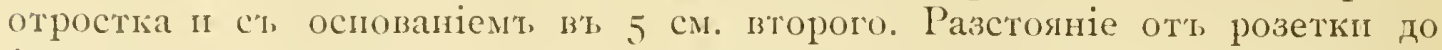
бугортатаго отростка- 2 см., до 2-го отростка $6 \mathrm{~cm}$. Окружпость розетки 7 см. Oкружност рога между отросткам $7 \mathrm{cm.}$

79 I 2 экз. обломков' рога.

$92-16$

$92-17$

$92-18$

$92-19$

$92-20$

$92--22$

I O I -5

SS-4і Обломок'т рога длиной от’ розетки до верхняго обломаннаго коцца по прямої 43 см. Остаток' перваго отростка еле замғтень, всльдствіе сильной потертости рога. Второй находится на разстояніи 9 см. оть розетки, а третіи на разстояніи 37 см. Окружность въ розеткы г 2 см. (розетка окатана). Окружность въ области третьяго отростка I 4,5 см. Найденъ въ Коровьемъ логу за воениым горогкомъ.

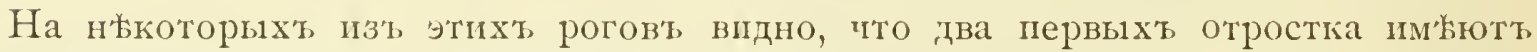
одно общее сплюснутое, лопатковидное основаніе.

88-i3 Правая пястная кость (metacarpus) молодого животнаго. Длина напо. I 7,5 см., ширина верхней сочеповной поверхпости 3,5 см., нижней- 4,3 см. Напм. ширина - 2 см. Напо́. толщина (спереди назадъ) 2.4 см. Т. I, фпг. 2 ).

88-i 5 Правый метакарпь (Mtс) (пястная кость) взрослаго индивцда, съ полу-

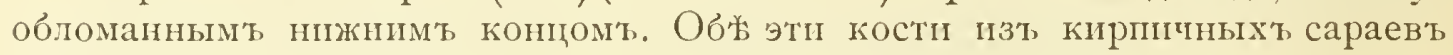
за военнымъ городкомъ.

90

IІравый Mtc (метакарпь- - ястная кость) взрослаго индивида. Напбольшая длина его 20 см. Ширнна верхней согленовной поверхности ок. 4 см., нижней--- 4,5 см. Наименьиал пирпна въ пижней четверті гости 2,5 см. Наиб. толцина (спереди-назадъ) ок. 3 см. Найдень въ Бирюсинской пецерж*). ('T. I, ф. I).

Эти костп (метакарпь) отличаются у этого вида своимъ глубоким заднимъ жолобомъ сращенія и для помњщ. мишцы п вообще сжатостью пхт съ боковъ. Въ то время, как` внугренній край спускается почти вертикально спереді назадъ другая-- внешняя сторона болже полога, по въ общемь боковыя стороны почти параллельны; хараптерна тажке слабая борозға, пдуцая по передней поверхности кости оть верха до нпжняго сосудпстаго отверстія и прполпжающцаяя к'т наружной сторонь гостп. Крайне характерна дугооразио пзогнутая назадт в' профиль задняя поверхность.

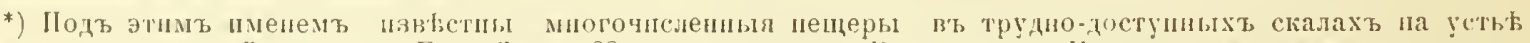

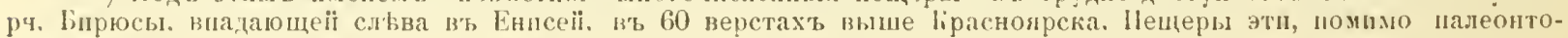

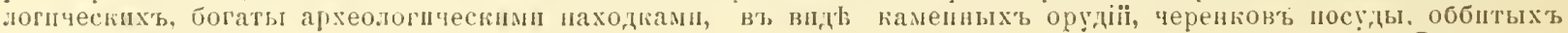
wocteï II T. д. $\mathrm{Pe}$ R. 
Лњвая большая берцовая кость (tibia). Верхній конец'ь этой кости обломан'ь ил не впдна верхняя суставная поверхиость. Нижняя поверхность пмћется со всъмп характерными прпзнакамп этого впда - узкая (справа нал'ьво) до 4 см., с’ь глубокими узкими жолобками для astragalus'a (таранной

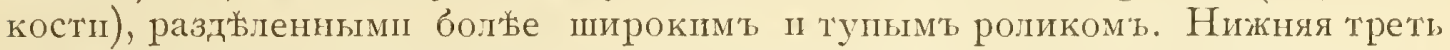
кости почти круглая въ разржзљ, слабо утолщающаяся къ верху п къ низу, 7 см. въ окружности. Наибольшая длина кости 3 I см., мъстонахожденіе-рч. Бирюса.

Болье пнтересными остатками этого вида въ коллекціи являются сльдд. № №:

88- 2 Часть герепа съ обломками рогов'ь пзъ кпрпичныхъ сараев'ь за военным'ь городвом' ('Т. І, ф. 6 а, в).

$88-5$ Іравая ншжняя челюсть съ молочнымп зубамп и сидящци еще вполнь

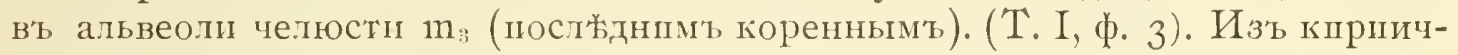
ных'ъ сараевъ военнаго горэдка.

$90-8 \mathrm{~A}$ Часть львой нижней челюсти.

$90-8$ Правая нижняя челюсть. ('Т. I, $\phi .3$ а, в, с). Ооза № № изъ культурн. погребеннаго слоя волииз Переселенческаго пункта, против' г. Красноярска.

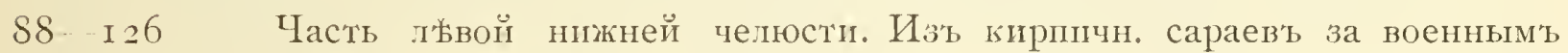
городкомом'

Вэ, череп务 № $88-2$ ('T. I, фиг. 6 а, в) сохранплись: затынопиая кость съ парой

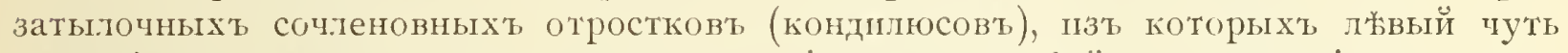
чуть обптъ, темянныя костп, вполн各 сросшіяся между собой п начннающія сростаться съ interparietalia; части лобных'ь костей с'ь обломками рогов'ь, части впсочных'ь II часть основной затылочной кости. Высота затылка от’ь верхняго края затылочной дыры (foramen occipitale magn11m) по прямой линіи 5 см. Напо́. пирина затылка въ області конднлюсов'ь 9,5 см. Очертаніе затылочнаго гребня полукруглое. На поверхности затылочной костп ясно выдыляются сильныя парныя углубленія и бугор' пाо средней пиніи надъ затылочной дырой, служпвшіе для прикрыпленія спльныхъ шейныхъ мышцъ. Напольшая длина темянныхъ костей по средней линіи сращенія (оть нея не осталось никакого сльда) отъ затылочнаго гребня до утла, входящаго въ шовъ между ossa frontalia (ловными костями) - 5 см.

Какъ сказано выпе, темянныя кости понти срослись ст interparietalia. Посіғдняя представляется здћсь въ вшдж бугорчатаго возвышенія, находящагося между краемъ затылочнаго гребня и срединой темянных'ь костей. ІШов’ между темянными костями и затылочной, подходя к' этому мњсту, начинаеть отступать отъ

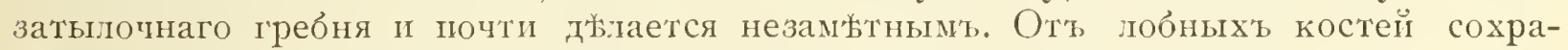
нплись незначительные обломіки съ отростками іл спдящими на нихъ рогами. Длина им'ьющагося шва между лобнымп костямп всего около $2-2,5$ см. Длина тобныхъ отростковъ до розетки около I, 5 см. Разстояніе между розетками роговъ на высоть⿱ т,5 см. оть средины лобныхъ костей-6 см. Окружность розетки льваго рога 8 см. На правомь рогъ сейчасъ же оть розетки замьтно отдынленіе перваго отростка. Длина обломанныхт роговъ всего 9-іо см. пा разстояніе между концамп их'ь на внутр. сторон'ь І 7 см.

Несравненно болье интереснымъ является сльдующій рядъ череповъ. 3 посльдніе черепа почти тождественны между собой и варіирують лишь в'ъ возрасть, о чем'ъ можно судить по швам's между костямп. По возрасту опп располагаются в'т спьдующем'ь порядк':

88-8 Самый молодой. Верхняя часть черепной коробки ('Таб̆л. II, ф. I а, b). 88-3 Черепная коробка (Табл. II, фиг. 3). 


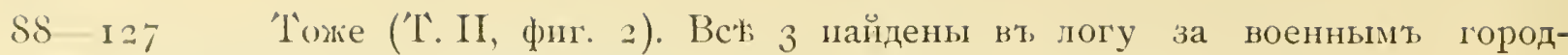
ком's, окр. г. Красноярска.

I 2- - 'Тоже. Самый старый (Табл. II, фиг. 4 a, b, c, d). Тазовскій носъ, 'lypyханскій край.

Въ смыслt: сохранности областей и костей нерена, послюдніе являются совер-

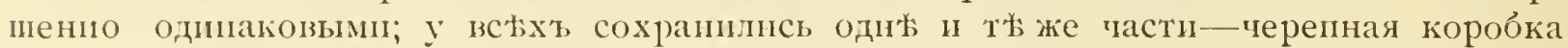
оть затыла до ея передняго паружиаго диа (до половины лобныхъ костей). Черент $88-8$ худшей сохранности п представляеть только верхнюю гасть той же оó.ласти черена.

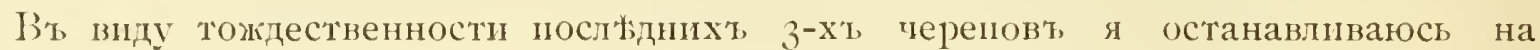
onncanin caмaro стараго, оолье лучней сохранности.

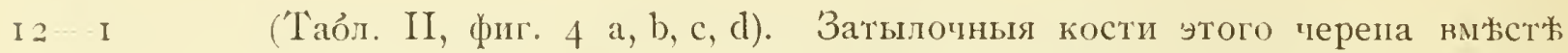
ст, сильно развитыми затылочными отростками (process. paramastoidens) придаютъ затылочному греóню полеречно овальное очертаніе. Затылочное отнерстіе (foram. occipit. magnum) почти круглое, нжсколько прижатое сверху. Затылопие кондилюсы съ ръзкимь перегпбом между верхней п пижней поверхностямп. Напольшая ширпна затылка надъ кондилюсами (между граями затылочнаго греóня) І 2,5 см. Высота затылочнаго грео́н, пад' нерхиимъ краемъ затылочнаго отверстія, по вертикальной пинін 5,5 см. Затылочныя кости совершенно слилисг съ находящимися нпереди ихь темянными костями. ШІиа, раздыляюцаго эти кости, почти не замьтно. Os interparietale (междутемянная) является о́угристой поверхностью, входящей далеко вт темянныя кости, съ которыми она совершенно слилась. 'Темянныя кости-посредиић черепа-длиной отъ затылочнаго гребня (т. е. вмьстен съ оs interpariet.) по шва съ лобными костями около 6 см.; ихъ иирина вт области этого ива между осиованіями роговъ всего 3 см. Ихт, боковыя 'асти спускаются узкой складкой пириной в'

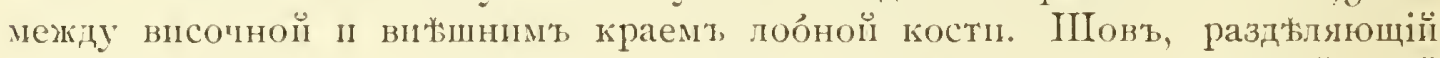

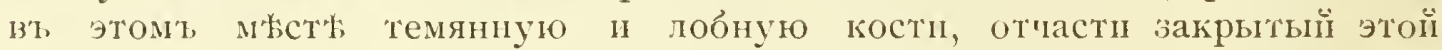
складкой, находится подъ ней и соверненно совпадаетъ съ внжшнимъ краемъ основанія рога. Височныя кости хорошо сохранились. Их'т каменистая часть (pars petrosa), отдњляясь ржзкпм швомъ отъ затылочной кости, почти совершенно слилась съ другой стороны съ, сооственно височной костью (pars squamosa). Барабанная кость (os tympanicum) является въ видъ пешраниьной трубки съ вогнутостью на нижней сторонњ. Скуловой отростокъ височной кості (proc. zygomaticus) почти цйликом' сохранился, въ особенности на лжвой сторонж. Еуто сопленовная поверхность (для нижней челюсти) иредстанляется, какт, у всъхх жвачныхт, вьиуклой, съ осью почти перпендикулярной оси терепа и съ вогнутой долиной сзади этой иыпуклой поверхности. Въ впсочной кости у основанія сочленовнаго скулового отростка находится одно въ 6 мм. въ діаметры нервное отверстіе и внереди отверстія углубленіе для прикрłпленія мышцъ. Длпна сохранпвшейся части лобшыхъ костей отъ темянного шва около 6 см. Почти сразу отъ этого пива лооныя кости начннаютъ

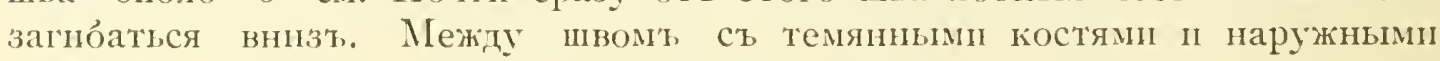
загио́ами складокъ, темянныхъ костей помњщщаются слабо-овальнаго очертапія основанія роговъ. Лобныхъ отростковъ, оо́ыкновенно поддерживающихт рога, въ этомъ, какь и въ сльдующихт черенахъ, нытъ, и розетка рога, повпдимому, прямо начннатась оть этого основанія, имњющаго пезнатительную вогнутость. Меньпій діаметръ этихъ основаній въ опи-

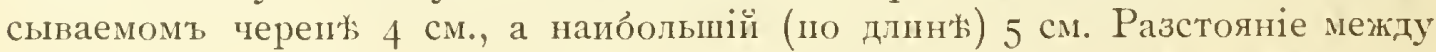
внутреиними краями основаній по лобному шву равно 4 см. Напменышее 
разстояніе между основаніемъ рога и затылочным гребнемъ 3 см. Въ основаніп черепа сохрапнлась оспонная костт, (os sphaenoidenm), песуцая большія крылья, совериенно почти слившіяся съ височными костямп. Отт, praesphaenoideum сохранплис тольо пезпантельные остатки иалыхт, крыльевт.

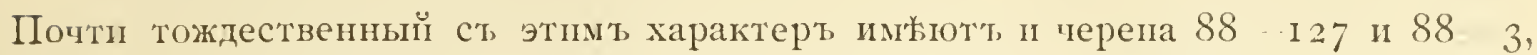
отличаясь пншь возрастомь п ньксколько пными пзмреніямп. Такт, напр., соотв ътственно возрасту, основанія роговъ имъють меньиій діаметрт.

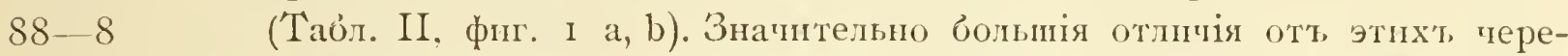
повъ имьетъ остаток' верхней части черенной коробки № 88 8. Судя по пвамь, правда нысколько стертымь, всльдствіе плохой сохрапности, и по основанію роговъ, этоть черепъ по возрасту можпо поставить самнмғ молодымт, изъ разсматриваемыхъ четырехъ. Но туть необходимо отм⿰-

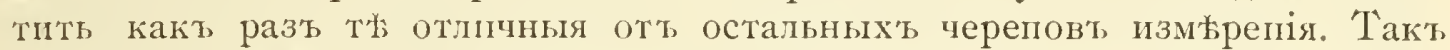

разстояніе между основаніями роговт (розетками) здъс, равно 5,5 см. (въ остальпыхъ черенах э оно равно около 4 см.). Діаметр'ь розетки равенъ всего только 3 см. Шпрппа темяннцхъ постей вт области лобнотемянного шва около 3,5 см. (у предыдущихъ не болже 3 см.). Боковыя

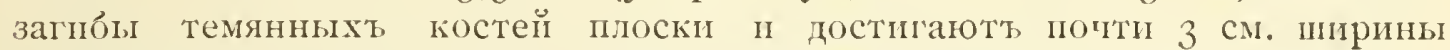

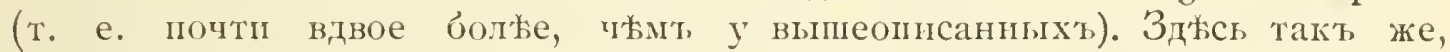
как'ь и в' предыдущихт, черепахъ, отсутствуеть, лобный вырость, п только замюттенъ незначительный подъемъ лобныхъ костей съ вогнутостью основанія рога. Разстояніе этого основанія от’ь затылочнаго гребпя то же camoe-3 $\mathrm{cm}$.

Несмотря на эти разпиія въ пзмреніяхь, я склонент, и этоть обломокь отнести этомуже впду C ervas tarandus fossilis, объясняя эту разнщц пипь возрастным отличіемь.

Что особенно пнтересно во всемъ этом'ь ряду черепов' -это то, тто разсмотржніе его даеть зависяцее оть возраста посльдовательое развитіе и измњненіе repera Cervus tarandus.

Направляясь отъ самаго молодого изъ этого ряда череповъ № $88-2$ (Табл. I, фиг. 6 a, b) черезъ сльдующіе по возрасту 88 8, 88 3, 88 г 27 и 1 2 -.. 1, постепенно можно просльдить ныкоторыя особенности возрастнаго пзмњненія костей и самой черепной коробкп. Первое и гтавное возрастное измьненіе; которое просльжено уже у других представптелей жвачныхъ (полорогихь)-это измьненіе затыл-

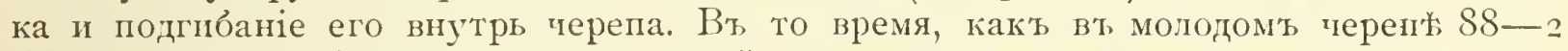
(Табл. I, фиг. 6) уголь, составленный темянными и затылочными костями, болье тупой и затылочныя кости п кондилюсы вытянуты нысколько назадъ, у остальныхъ, бол⿻е взрослыхъ череповъ, этоть уголт почти равенъ прямому, и затылочные кондилюсы немного выдаются изъ вертикальной плоскости затылочнаго гребня. Здъсь затылокь какт, бы поджать впередъ (внутрь) черепа.

Спьдующее измюненіе заключается въ деформаціи темянныхъ костей. Ихъ верхняя часть, вклинивающаяся между лобными костямп, ст воз́растомь не увели-

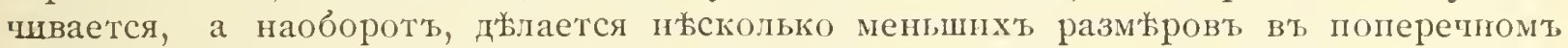
направленін. Не пзмьняется и ихъ длина, и разстояніе между затылочнымь гребнемъ и основаніями роговъ остается везд од одинаково. Но гтто особенно интересно въ пзмьненіп темянныхъ костей, то это пзмєненіе боковыхъ загпоовъ, входяцихт, между височной и лоӧной костями. Измжненія заключаются в'ь томь, что боковые загибы темянныхъ костей пзъ болье широкпхт и плоскихь въ молодомъ возрасть, преврацаются вт, болье узкіе и выпуклые. И это уменыненіе ширпны ихт, является сльдствіемь того, тто верхняя часть этихь боковыхь отростковт, вблизі наружнаго края рогового основанія, собирается в’ь толстую складку, закрывапоцо собой, какт было указано, шовт между лобной ит темянной костью. 
Всж указанния возрастиыя измненія легк, по моему мньнію, объясняются

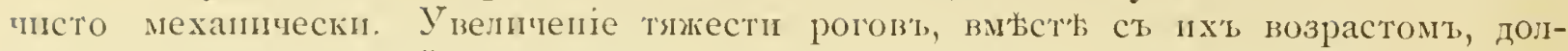
жно требовать больией поддержк и усиленія лобных костей подь пими. Дапленіе

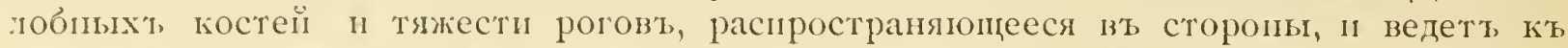
захпату побным постми тасти, занятой ранже темяниын. Еще больше давленіе па пиншнюю сторону, па которой лобныя кости граничать съ боковыми загибами темянныхт костей. И это больнее давленіе и пропзводить ту характерную складку боковыхт, загнбовт, па жоторую пыне указывалось. Здљсь это давленіе, как' в' средней пасти темянныхт костей, не могло идти ит, направленін захвата и уменьпенія ширнны темянныхъ загибовт, такт какт этимт уменыналась бы опора рога, создаваемая этой спльной складкой.

Все это осољенно хоропо впдно па терепахъ $88 \cdots-2,88-8,88-3$ и г 2- I;

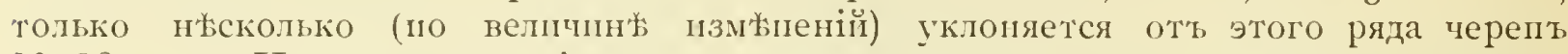
№ 88-i27. Но его уклоненіе можно отчасти нризнать чисто пндивидуальнымъ, при которомь складки темянныхъ загибовъ выражены меные ясно, такь же, какъ и пндивидуальо отличе этого черепа в’ том'ь отноненіи, что его лобныя кости отличаются большей выпуклостью в’ь поперечном' направленін, чьшт у другихъ череповъ разсмотржннаго ряда.

Перехожу к'ь оппсанію упомянутыхь випе челюстей ст полным зубнымъ рядом' На всљхъ пзъ нихь сохранились всъ зуо́ы, какъ настоящіе коренные,

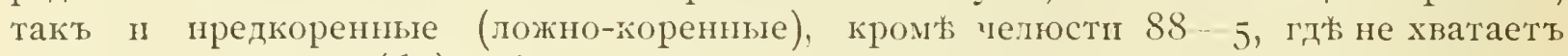
мологнаго перваго $\left(\mathrm{d}_{1}\right)$ зуо̆а.

Здъсь я постараюсь дать подробное описаніе этихъ челюстей в’ь той поспьдовательности, которая должна дать яспое иредставленіе объ измыненіи какъ жевательной поверхності, такь и самихь зубов' вт различнмт возрастћ у одного и того же вида животиаго, въ данном' случа' Cervus tarandus fossilis.

88-5 (Табл. I, фиг. 3) является челюстьо молодого оленя. У него сохранились еще всы молочные зуо́ы. Вт, то время, как' второй настоящій

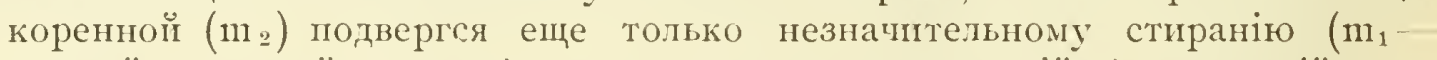
первый коренной стерся болье-какъ ранъе появившійся) посльдній, тре-

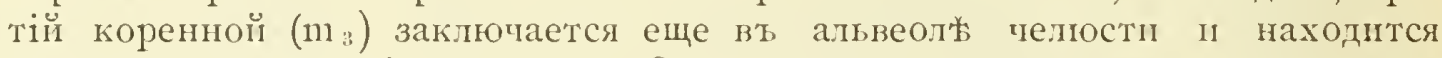
въ періоды появленія на свғтт. Отъ этого $\mathrm{m}_{3}$ мы видим' только одну переднюю пару луночекъ, пз которыхъ одна (наружная) сломана. Средняя складка эмали какдой луночки какт этого ( $\left.\mathrm{m}_{3}\right)$, такъ и двухъ сльдующихт $\mathrm{m}_{2}$ п $\mathrm{m}_{1}$ коренныхъ зубовт, такь же, какъ и завернутость угловъ луночек', внутрь, даст’ь при стиранін угловато-крутлое очертаніе

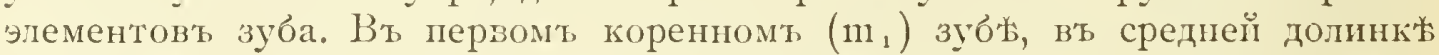
наружно̆ стороны зуба замжтенъ слабый намекь па добавочный буторок’ (ципфель), который у Cervus tarandus не развивается болье сицно. Вмбето постоянньхт предкоренныхъ зубов'ь в'ь этой челюсти пмжются

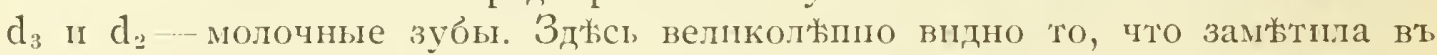
своихъ работахт М. В. ПІаллова, тто молопные зубы являются спожнже

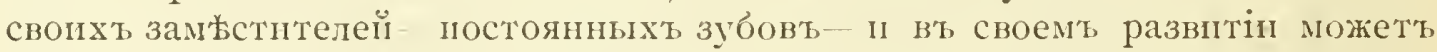
быть предсказывають дальньйшее развптіе характера зубов'ь, так'ь какъ считать эту сложност, эмбріональнымь пережпткомъ-возможнымь не является, в'ь впду того, тто подобная сложности, постоянныхъ зубовъ еще не наблюдалась у исконаемых' форм'т. Большая же сложность молочныхъ

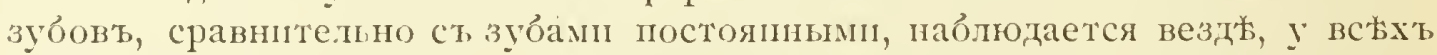
млекопитаюцих. $\mathrm{D}_{3}$ иъ разсматриваемой челюсти, паходяційся вљ посльднемт, періоды стиранія (передт выпаденіем'ь), ясно состопть пзъ трехт паръ луночекъ, пзт которыхь передняя пара развпта болье слабо, чьмъ спьдующія. IІара задняя является правильно развптой, пара же средняя 
свопмъ сліяніемъ съ наружной образовали довольно пространную поверхность, подраздћленную только однимъ междулуночным' углбленіемтзаливомю. Болье ясно указынають на это дылепіе наружная и внутренняя сктадки эмали, входящія внутрь зуба. С`ь наружной стороиы въ допиикж между задней и средией парами пуночекъ находится яспо выражениый ципфель, который при стираніи далт, поверхность треугольнаго очертанія. Второй молочный $\left(\mathrm{d}_{2}\right)$ зубъ-тоже передт свопм' выпаденіемъ. Его стертая, съ переломомт на срединж поверхиость подраздљлена двуми островками эмалг, по которымт можно заключпть о присутствіи въ немт также

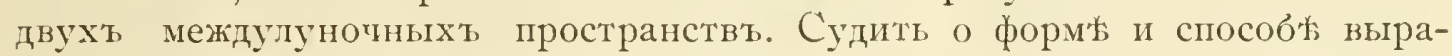
женія этпх поверхностей на нестертомь зубъ не является возможнымь, почему вся форма этого зуба не можеть быть возстановлена. Задній островокъ является только незначительнымъ бугоркомь еще не слершейся эмали, представляющимт собой повидимому дно стертаго междулуночнаго пространства-углубленія. Второе междулуноиое углубленіе ясио выражено ямкой эмали треугольнаго очертанія.

Благодаря пзлому челюсти въ области этого зуба, намъ видень находящійся внутри челюсти постоянный предкоренной зубъ (ре), который и появился бы

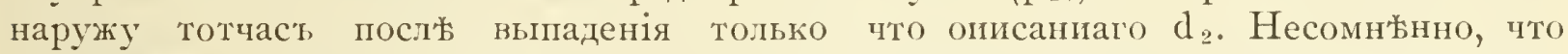
подобный же зубъ (конечно $\mathrm{p}_{1}$ ) находится внутри челюсти и подт зубомь $\mathrm{d}_{3}$, который также описань. Такой же зубт находился п подъ отсутствующимъ $\mathrm{d}_{1}$. Теперь сльлуеть еще остановнться на пзьреніи. Длина зубовъ (сзади-напередъ): $\mathrm{m}_{2}=23$ мм., $\mathrm{m}_{1}=22$ мм., $\mathrm{d}_{3}=24$ мм., $\mathrm{d}_{2}=8$ м. Высота челюсти вт области между $\mathrm{m}_{1}$ и $\mathrm{d}_{3}=33$ мм. Пятка челюсти пменет характерную оторошенность внизъ. Сопленовный отростокъ челюсти обломанъ.

90--8 А Сльдующимт по возрасту является зубной рядт, представленный львой челюстью № $90-8$ А. Останавливаться на немт не буду вт виду того, что все сказанное придется повторять при описаніп сльвғ. №, который опииу подробнже. Разнпца в' этихъ двухъ челюстяхъ (относительно чисто одонтографическихъ иризнаковъ) заключается только въ томъ, что челюсть № $90-8$ - А менъе стерта, ч安м сльдующая, т. е. немного моложе. Зубъ $m_{1}$ (первый коренной) поврежденъ-обломана его ннутренняя сторона.

9о- 8 Я описываю эту челюсть изь двух сохранности. Это - почти совершенно цћлая правая челюсть (Т. I, фиг. 4 a, b, c) съ полнымъ зуонымъ рядомт, чуть-чуть большей стертостью, чимт у предыдущей. Эту челюсть можно сразу поставить посль описанной челюсти $88-5$, чтобы сравнить молодую и взрослую челюсти.

Зджсь уже совершплась перемњна въ томь отьошеніи, что молочные зубы всж смьнились постоянными предкоренными Іп появился уже въ степени незначптельнаго стиранія и третій коренной $\left(\mathrm{m}_{3}\right)$ зубъ. Характерная сжатость этих зубовь с’ь боковъ является однимь из' признаков'ь вида Cervus tarandus.

$\mathrm{M}_{3}$ представляется тремя парами луночек'ь, изъ которыхъ посльдняя, задняя, развита очень слабо п болье, ч出ь вдвое, меныне первыхъ лунокъ. Эта третья пара лунокъ въ данной челюсти еце почти не стерта и съ внутренней стороны челюсти видио, что она на внутренней сторонь дьлится складкой эмали на 2 зубовидныя части, изъ которыхт задняя сливается незамғтно потти ст лункой наружной. Сльдуюція пары лунок' так' же, какъ и на коренномт втором' п

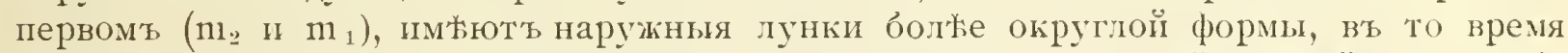
какъ лунки, обращенныя внутрь челюсти, олличаются угловатой формой, всльдствіе ръзкпхъ складокь эмали внутренней стороны зуба. В т́ степени стиранія, подобной той, какая имћется в' описываемой челюсти, замътно, что при стираніи передняя 


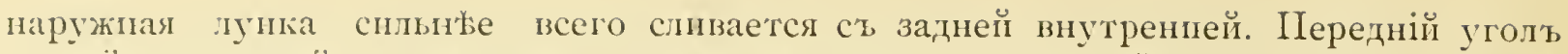
задней паружной луни подходит и спинется съ передней паружной же лункой

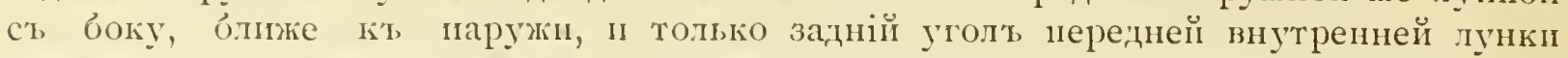

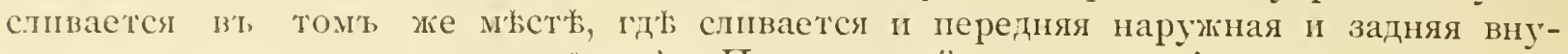

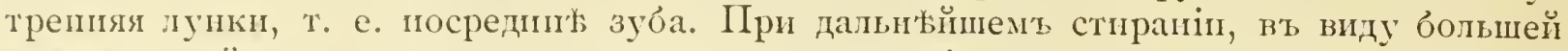
пли менцией пнтепсиниости складок'т кт основанію зуо̆, эта иравильность можетъ

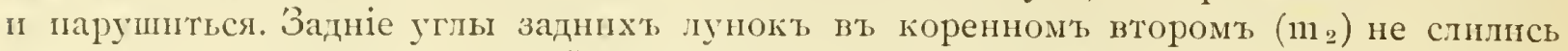
епце, так'ь же, как'т и заниій угол'ь иередне-внутренней лунки п передній уголь задпе-паружиой лупи въ 111 . Не виолиж сливиимися являются п передніе углы

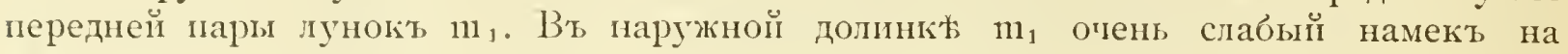
цимфель.

Одиой изт характернихь особепиостей предкоренного перваго ( $\left.\mathrm{p}_{1}\right)$ является его различіе вт длинь коронки (спереди--назадъ) вверху п винзу. Длина его вт основаніи коронки д 5 м., а вверху і 9 м. Это пропсходить всльдствіе гого, что задне-паружиый бугорокъ зуба, сплоценный въ діагональную складку эмали, ши роко отставляетея такт же, как'т и в' сльдующем' пазадъ. Задне-внутренній бугорокъ сливается діагонально съ задним утломъ наружно-передней луночи, оть которой въ этомь м⿻йсть, болье глубоко (еще подт, поверхпостью стпранія) панььается складка, соеднняюцая эту лунку съ передне-гаружной. То же самое должпо сказать и обо всемт р. зубъ, только зджсь складка, соеднняюпая переднія внутренпюю и наружную лункп уже подверглась стиранію. Туть кстати указать характерный отличитеньный иризнакъ этихь зубовъ, собственно оленьихъ, отъ зубовъ лося-уже не говоря про другіе признаки. Это то, что здьсь (у собственно оленеї) передняя часть, половнна зуба $p_{1}$ не составляетъ по сноему сходству передней половииы сльдующаго коренного перваго $\left(\mathrm{m}_{1}\right)$ зуба. У посей эти тасти соверпенно тождественны. $\mathrm{P}_{3}$ - третій предиоренной состопть пзт задней складки, совершенио сходной со складкой задне-наружнаго бугорка предыдуцихт р. II $\mathrm{p}_{1}$. Она не вполнњ сливается съ остальной частью зуба при пмьющейся степени стиранія. Остальная, больпая тасть зуба состоить изъ трехь больпихт внутренних складокъ и четвертой наружной, сходящихся всжх'

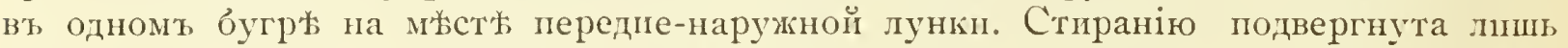
задняя половина зуба. Напбольшая длина верхней поверхности зубовъ: $m_{3}=25$ мм., $11_{2}=22$ мм., $11_{1}=2 \mathrm{I}$ мм., $\mathrm{p}_{1}=\mathrm{I} 9$ мм., $\mathrm{p}_{2}=\mathrm{I} 7$ мм., $\mathrm{p}_{3}=\mathrm{I} 3$ мм. Наибольшая диина челюстп по пиніи, проходящей $\mathrm{y}$ основанія зубовт оть задней пяткі до передней челюстной дыры, 2 I,5 см. (передній конець челюсти обломань и взять настоящую длину не представляется возможным). Высота челюсти между м и и $\mathrm{p}_{1}=$ 3,2 см. Высота сочленовной поверхиости надт пяткой (отъ нижняго копца пятки) І о см. ІІІирина сочленовнаго кондилюса (обтертъ) 23 мм. Кондилюсъ слабо вогнуть. Его положеніе почти перпендикулярно къ оси челюсти, съ слабымъ уклономъ его

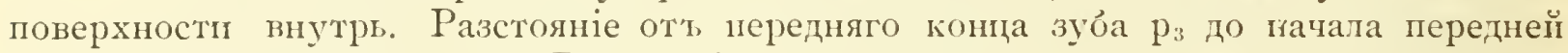
челюстной дыры $=40$ м. Разстояніе оть задняго попца $111_{3}$ до натала задней (внутренней) челюстно̆ дыры $=30$ мм.

88- - 26 Болье старую львую челюсть представляеть № $8 \delta$-- I 26 . Прі сти-

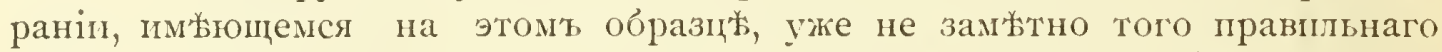
сліянія угловь луночекъ, о которомъ говорнлось выне (задняго угла передне-наружной и нередняго угла задне-внутренней лунокт). На этой

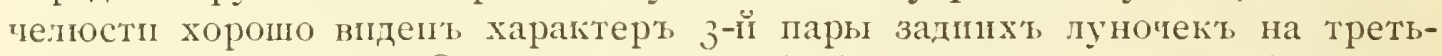
емт коренномь $\left(\mathrm{m}_{3}\right)$. Они въ своемь сліяніи другъ съ другомь ооразують труо́оку, дающуюю при стираніи кружокъ, отдъленный от’ средней пары

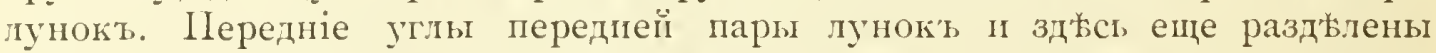
огень тонкой щельо продолженіемт долини, паходящейся между передпей парой лунокь. Задніе углы задней пары тунокт пе раздылены подобной же щелью. Какь сказано выне, туть нельзя уже подмжтить правиль- 
ной посльдовательности въ сліяніи угловъ лунокъ, но па $\mathrm{m}_{1}$ все-таки замбтно это чередованіе угловъ. Что касается предкоренныхъ зуо́овъ, то здысь, сравнительно съ предыдущей челюстью, остается залытить только большее сліяніе пхъ складокт, какъ результать болже сильнаго стиранія. $\mathrm{Ha} \mathrm{p}_{1}$ передне-пнурепня лунка уже слплась совершенно свопи задним углом с', передне-наружной и съ заднимъ внутренпимь бугром⿰. 'Го же II на $\mathrm{p}_{2}$ iा на $\mathrm{p}_{3}$, гды все-таки еще ясно видны всж складкі, но одна -вторая спереди начпнаеть псчезать. Кром то тог, она здысь является не самостоятельной складкой, а какъ бы только складочкой на третьей спереди складкь. Это ея недоразвпте ведеть кь тому, что соедннявшійся съ нею на предыдущей челюсти передне-внутренній бугорок'ь, здъсь является совершенно от' нея пзолированиым глубокой долинкой. Длина зуо́овъ: $\mathrm{m}_{3}=24$ мм., $1 \mathrm{1}_{2}=20$ мм., $\mathrm{m}_{1}=22$ мм., $\mathrm{p}_{1}=\mathrm{I} 8$ мм., $\mathrm{p}_{2}=\mathrm{I} 7$ мм. и $\mathrm{p}_{3}=\mathrm{I} 3$ м. Высота челюсти между $\mathrm{m}_{1}$ и $\mathrm{p}_{1}=28$ мм. Разстояніе оть конца зубного ряда (отъ конца рз) до передней челюстной дыры 45 мм.

Далће къ этому впду относятся обломки челюстей:

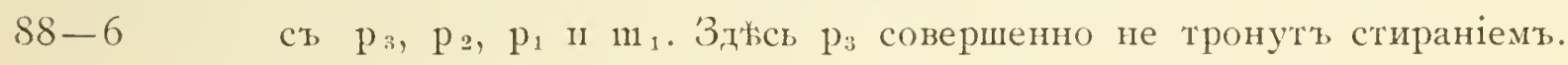

88--6 съ р. пі р: іг, наконець,

793 ооломокь правой пелюсти съь совершенно стертьмт п1 п очень стертыми $\mathrm{p}_{1}, \mathrm{p}_{2}$ и $\mathrm{p}_{3}$.

Всь этн обломки изъ лога кирпичныхъ сараевт, за военнымъ городкомъ, во́лизи г. Красноярска.

\section{Cervus maral Ogilby.}

\section{(Cervus elaphus var. canadensis, var. maral Tscherski).}

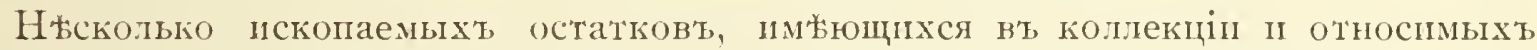
мною къ Cerrus maral (Cerr. canadensis var. maral Tscherski), кь сожальнію, только гадательно относяся кь этому ниду, за отсутствіемъ сравнителыных матеріаловъ. Эти остатки незначтельно отличаются отт Cervus elaphus. Iри описаніи

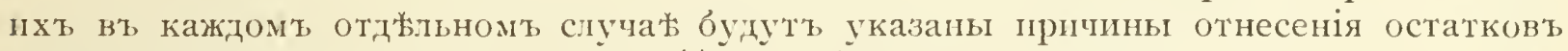
къ Cervus canadensis var. maral 'T'scherski, а не к' настоящему олагородному оленю (Cerv. elaphus).

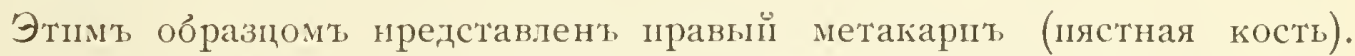

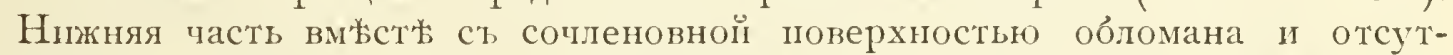
ствуетъ. ІІІирина верхней сочленовной поверхности 5,5 см. Напболыная толщина (спередп назадъ) 4 см. Напменьшая ширина самой костп мета-

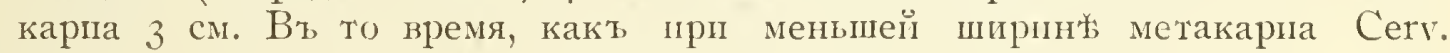
elaphus, оппсаннаго M. В. Павновой̈), длина всей кости равна 27 см., здысь дппна обломанной кости равна $25 \mathrm{~cm}$. п на продолженіе ея до предполагаемаго окопчанія пеобходпмо увеличить эту плину до $28-30$ см., т. е. пными словамп, описываемый метакарпь прп болышей длинж имжеть ту же ширину метакарпа типнчнаго Cerv, elaphus, т. е. янляется болюе длиннымъ п болье стройнымъ. Въ то же время этоюь же мегакарпъ пмиеть верхнюю сочленовную поверхность, значителью превосходящую своей величиной размћры поверхности метакарпа, изображеннаго въ той же работь М. В. ІІавловой (ширнна пзображеннаго на табл. IV, ріс. 23, равна 4,8 см.). Кром' того, борозда, проходящая на передней поверхности оть питательныхъ (сосудпстыхь) отверстій, въ описываемомъ экземпяры 


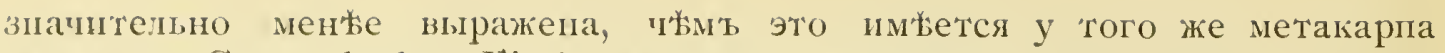

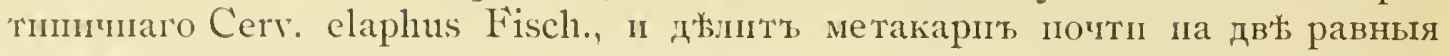
части.

Јџиый берег”, р. :нисея, пер. Бирюса.

S9- 7 Обломокт, рога окружностьо въ розеткж г7 см. Разстояніе оть розеткі до глазпнинаго отростка (обломанъ) почти около 3 см. До 2-го отростка отт розетки (по прямой линін) І 2 см. Окружность рога между отростками 14,5 см.

Отличіе этого рога отт рога тmичнаго Cerv. elaphus заключается въ томъ,

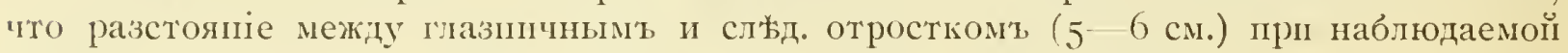
толщин; рога-- болье велико, тым у настоящаго Cerv, elaphus.

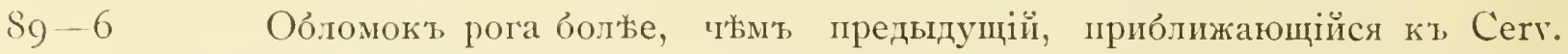
elaphus по меньшему разстоянію между г-мъ и 2-мъ отростками, которое ранно всего только 3 см. Окружность розетки 2 о см. Сразу отъ нея налннается глазниный отростокь, отъ котораго па образц' сохранилось, лини самое основаніе. На разстояніп 28 см. оть розетки по прямой, на внутренней сторонж рога находится остатокт отъ 3-го отростка.

Оо́а оппсаниые обломка найдены па р. Манж, Красноярскаго у॰, въ $3-5$ нерст. оть нос. Нарны.

Еще болье подходящими къ Cervus elaphus стоятт спьдующіе образцы:

Обломокт рога очень стараго пндинида, судя по его величнны, Къ сожальнію, точно дать размьры рога нельзя, въ ниду большой трецины, ироходящей ндоль. Окружность розетки 25-26 см. Сразу же отъ розетки отходить глазничиый отростокт, съ окружностью въ мисть облома (вт, основаніп) I4 см. и черезъ 4 см. находится 2 -й отростокъ ст, окружпостью в’ основаніи 12 см. Весь 2-й отросток' (онт, сохранплся почти до конца) янляется грулымь пь разрьзы. Его дыйа по прямой 17 см. Рогъ, у второго отростка и пенног ныше (на $4-5$ см.) силюснуть на сто-

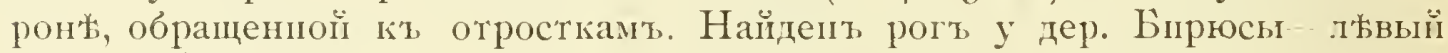
бер. р. Енисея.

66

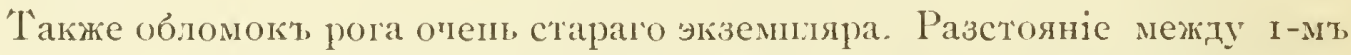
и 2-мь отростками сонершенно незианительно- I 2 см. Но размьры этого рога значительно превосходя'т размжры типичнаго Cerv. elaphus, даже стараго пндивида. Окружность розетки 28,5 см. Окружность основанія I-го глазничнаго отростка I9 cм., 2-го- 16 см. Окружность стержня за 2-мъ отросткомъ на разстояніг 8 см. отъ посльдняго- 9 см. Къ верхпему обломанпому концу рогъ изъ круглаго пренращается какъ будто въ †-угольый опевидно, здысь было мжсто 3-го отростка, передъ основаніемъ котораго пा отломленъ рогъ. Дипна отъ розетки до этого основанія по прямої (на внутренней сторонь рога) 27 см. Виутренняя сторона рога въ области г-го и 2-го отростка совершенно плоская. Весь рогъ покрытъ продольнымп параллельными скульпурными полосами. Р. Камынта, Минусинскаго ужзда.

\section{Cervus euricerus Aldr.}

\section{(Cervus giganteus Blum., Cerv. megaceros Hart.).}

Этому крайне пнтереспоу виду въ описынаемой коллекціи принадтежать только немногіе образцы, несмотря на то, что область распространенія этого вымершаго животнаго включала въ себя п всю Сиблрь. Находкі отдыльныхъ костей его были совершепы въ Зап. и Восточной Сио́ири, вплоть до Іріамурскаго края.

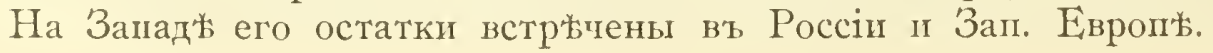


Обломокъ рога съ частью лобной кости, сохрапивней гасть оро́ить.

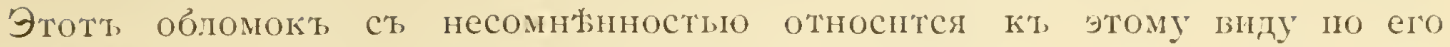

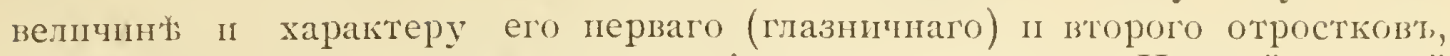
находящпхся на больпонт разстоянін другъ отт друга. Шервцй гтазной

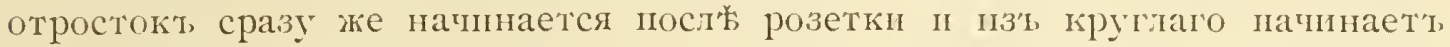
расширяться вт, падглазниную пластинку рога. Впрогемт, это не всегда бываеть такь и случается что пластннка пе овразуется - тогда отростокт,

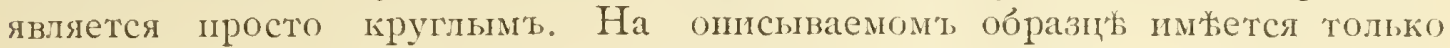
сльдъ отъ этого отростка на стержнж рога. Наиоольшая длина рога по прямой отъ розетки 3 см. Окружность розетки ниже глазнптиаго отростка (который идеть сразу посльв замжнной розетки) 26 см. Окружность рога въ наталь пзлома, на разстояніп $\delta$ см. оть розеткі по внутреннему боку- I 8 см. Разстояніе оть г-го до 2-го отростка 20 см. Мњстонахожденіе ри. Камынта, Мпнусинскаго ужизда.

Этому же виду нужно отнести іп первый шейный позвонок' (Atlas), найденный на львомт берегу р. Енисея, у дер. Бирюсы. Его трапецоидиая форма сь большой, ппрокой задней поверхностью п узкой нередпей, является характерной для этого вида, почему ее легко отдылити оть почти

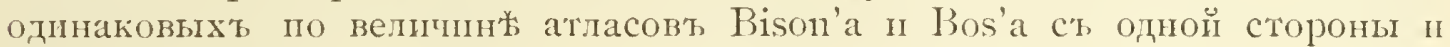
Alces ст тругой.

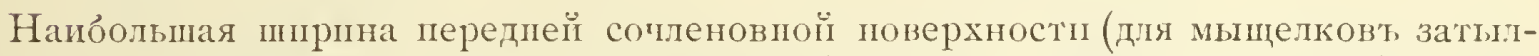
ка) I 2,5 см. Щприна задней поверхності (для 2-го пейнаго позвопка) г 3 см. Наиоольшая ширна въ крыльях` (боковые отростки) 24 см. Длина тьла позвонка (нижней поверхності по среднн出) 6 сл. Длина верхней дуги оголо 8 см. Наибольшая длина позвонка виьсть съ прылгямі около і 4 см. Нанбольшая высота около I с сл. Задияя сочленовная поверхность для Aхіs'a (2-го пейнаго позвонка) вмбстю) съ концами крыльевъ представляетъ ровную, мало выгпутую, плоскую дугу, между

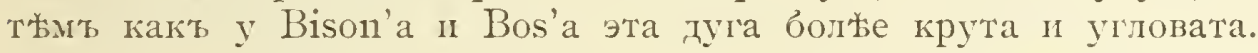

('Таб.. III, фиг. I a, b, с). Очень пнтересный остатокъ представляетъ соо̆й правая нижняя челюсть, сохранившая всъ зубы, найденная в’ галечныхъ отложеніяхъ окрестностей г'. Канска. Она нысколько обломана

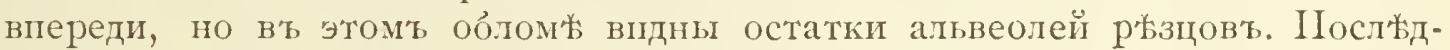
нихъ, судя по этпмь отверстіям' было 3. Задняя часть челюсти с’ь пяткой, сочленовнымя, п вънечнымъ отростками отломана. Длина челюстной кости между краями передняго наружнаго и задняго внутрепняго сосудистьхъ отверстій 26 см. по прямой линіп. С o,5 см. впереді послюдняго предкоренного зуо́а іл на I,5 см. ниже верхняго края челюсти имнется второе наружное, очень маленшое сосудистое отверстіе. Длина зубного ряда равна I4,5 см. Разстояніе между посльғнимъ кореннњм’ зуо́омъ и задней стороной большого наружнаго сосуднстаго отверстія равно 6,5 см. Высота челюстной кости между m $_{1}$ и $\mathrm{p}_{1}-5$ см.

Носльдній коренной зуољ $\left(\mathrm{m}_{3}\right)$ состоптъ пзъ трехъ паръ луногекъ, изъ которыхъ задняя пара развита слабъе переднихъ п пметъ болье округлое, безъ внутренншх углов', очертаніе. Наружныя лунки как', этого, так' п сльдуюпаго $\mathrm{m}_{2}$ зуба, сжаты съ боковъ, на жевательнй поверхности округло треугольной формы, съ вершипой, нжсколько ооращенной назадт, челюсти. Оспованіе этихт, пунокъ почті полукругло випукло наружу, с’ь пезначптельпой деформаціей. Наружпая средняя лунка $m_{3}$ не слплась еще свопм углами ст пуной виутренней,

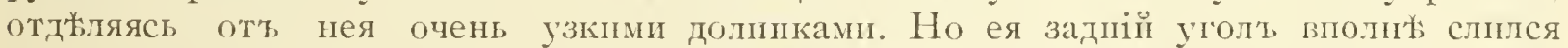

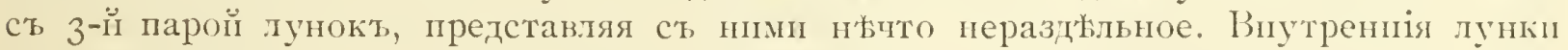
этихт, зуоовь вт, средней тасти ромбопдальны, вытянуты въ передне-заднем' направленіп и въ заднихт лункахт почти ровно округло сливаются с'т утламп наружных тунокъ, тогда какт въ лункахт, передних, образуются еще в', углахт, 
скиади эмали, обращенныя внутрь челюсти. Эти складип на заднихь лункахъ, хотя тоже присутствують, по огень мало выражены. Совершенно другую картину, всльдствіе спльнаго стиранія, представляетъ $111_{1}$, въ которомъ заднія лунки все-таки

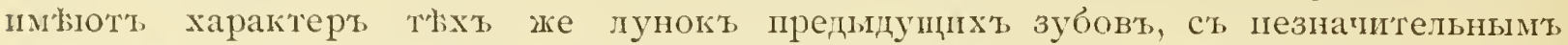

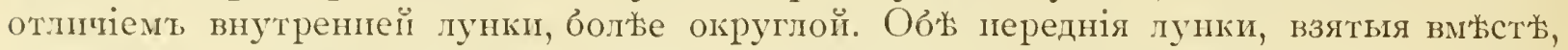
образують почті правильо груглую поверхность, подразджленную небольшимъ островкомъ эмалп, паходяцимся ближе к's переднему краю окружности. Всъ

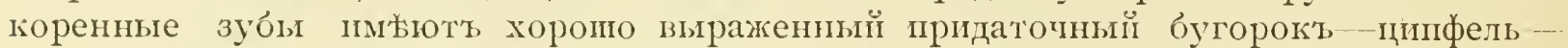
находяційся въ наружпой допннкћ зуба (с на фпг. І, табл. III). М ципфель въ передней долинь зуба. Длина каждаго ципфеля пе превышаеть 3 мм. Вэ $m_{1}$ ципфель находится уже въ незначптельной степени стиранія.

$\mathrm{P}_{1}$ образованъ двумя парами лунопекъ, изъ которыхъ задняя пара вдвое меньше передней. Она подразджлена маленьким островкомъ эмали. Въ противуположность лункам' коренныхъ зубовъ, которыя выстранвались въ діагональномъ направленіп, съ наружной пункой, обращенной к'ь заду-эта пара лунок' р 1 обращена наружной пункой впередъ. Глубокой наружной и внутренней складками эмали, эта пара отдћлена оть передней болышей пары лунокъ, также раздљленныхъ въ центрн эмалевымъ углубленіемъ. Огертаніе наружной луни правпльн полукруглое, край же внутреннеї пунк угловато иломань с`ь вогнутостью внутрь зуба въ передней

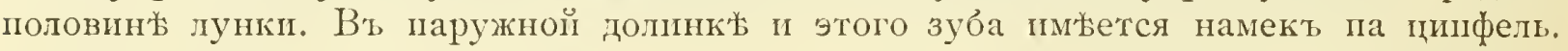

Совершенно другого зида $\mathrm{p}_{2}$ и $\mathrm{p}_{3}$. О人́а сжатые съ боковъ, они вовсе не представляю'ь въ своемь строеніи элементовъ лунок'. $\mathrm{P}_{2}$ является продолговато треугольнымъ зубомь съ слабо волнистой наружной стороной. Внутренняя сторона собрана въ рњзкія складки. Три изъ такихъ рызкихъ, узкихъ складокъ образують заднюю полонину зуба (бол⿻е丿е расширенную). Въ передней (узио̆) тасти зуо́а складка образуетъ внутреннее утолщеніе жевательной поверхности. Такія же двъ

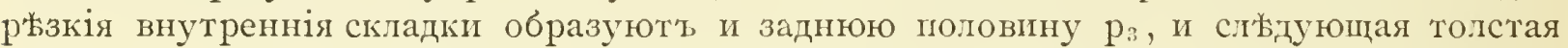
складка, слегка раздвоепная, расширяетъ жевательную поверхность какъ разъ на ея срединьь。

Наибольшая длина зубовь: $\mathrm{m}_{3}-3^{8}$ мм., $\mathrm{m}_{2}-3^{2}$ мм., $\mathrm{m}_{1}-23$ мм., $\mathrm{p}_{1}-2 \mathrm{I}$ мм., $\mathrm{p}_{2}$ - 22 мм., $\mathrm{p}_{3}$ - I6 мм. Наибольшая ширина зубовъ: $\mathrm{m}_{3}-\mathrm{I} 3$ мм., $\mathrm{m}_{2}$ - I5 мм., $\mathrm{m}_{1}$ - I4 мм., $\mathrm{p}_{1}$ - 12 мм., $\mathrm{p}_{2}-9$ мм., $\mathrm{p}_{3}-5$ мм. Ширина бралась у $\mathrm{m}_{3}, \mathrm{~m}_{2}, \mathrm{~m}_{1}$,

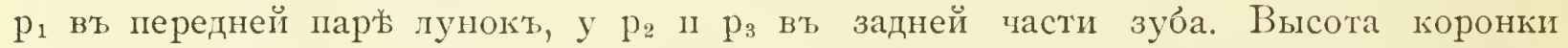
зубовъ посрединьь-въ долинкахъ: $m_{3}-22$ мм., $\mathrm{m}_{2}-\mathrm{I} 7$ мм., $\mathrm{m}_{1}-8$ мм., $\mathrm{p}_{1}-$

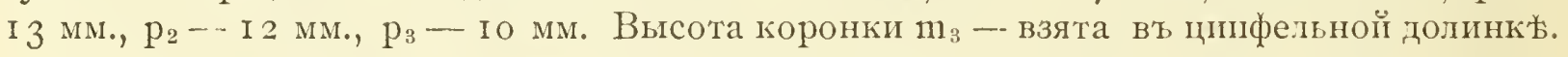

Высота челюстной кости между $\mathrm{m}_{1}$ и $\mathrm{p}_{1}-5$ см.

Какъ измьренія этой челюсти, такъ пा характерь зубовъ, въ особенности предкоренныхъ, говорятъ о принадлежности этого ископаемаго остатка виду Cervus e uricerus. Но вмњсть съ этими, почт тождественными особенностямн челюсти съ типичнй челюстью Cervus e uricerus, въ описываемомь образцы пмьются и уклоненія. Эти уклоненія касаются указанныхъ выше ципфелей. Въ то время, какъ въ типичпо̆ челюсти Cerv. euricerus, описанной п пзображенной въ работь́⿱一土㇒ М. В. Павловой-Sélénodontes posttertiaeres de la Russie въ единственной, повидимому, работ出, гден изображепа челюсть этого впга, пмғются ясныя указанія па прпсутствіе въ $1_{3}$ двухъ ципфелей-въ обопхъ наружныхъ долинкахъ зуба. Кромь того, величина ципфелей тамъ достигаеть больших размъровъ (оть 7-- го мм.). Въ напемъ образцж, какъ указано выше, ципфели выражены значительо менће, п совершенно отсутствуеть ципфель во второй (заднеї) долинкь зуба $\mathrm{m}_{3}$. Къ сожальнію, въ просмотржнно̆ мною литературь, я не могъ найти указанія на характерность присутствія или отсутствія этого ципфеля. Во всякомъ случаъ другія особенности, почти тождественность этой челюсти съ рисун. комъ указанной работы, позволяютъ мнж отнести эту челюсть къ віду Се rus euricerus. 


\section{Cervus cf. pigargus. \\ (Capreolus pigargus Pall.).}

A-88-гі7 (Табл. III, фиг. 2 a, b). Имьющқійся в’ь коллекціи обломок' черепа сохраниль всю черепную коробку, съ лобными костямн, почти доходящпми до носовыхьь костей. Почти цилпдрическая терепная коробка является только незначптельно вздутой въ теминыхъ костяхъ, сравнительно съ областью соеднненія темянных`ь костей с’э лобными. Затылочная кость, съ спльно выдающимся срединным' вертпкальным мускульнымъ гребнемъ надъ затылочнымъ отверстіем' п мускульными углубленіямп по бокамъ его, хорошо сохранила кондилюсы і слегка только обломана въ углахъ, ооразующихь proc. paramastoidei. Эта кость является совершенно слиншейся съ оs interparietale, которая входитьь наверху черепной коробки тупымь угломь межху темянными костями. Очертаніе затылочнаго гребня сзади округло треугольное. Напо́ольшая ширнна затылка в’ь области кондилюсов'ь около 8 см. (углы затылка обломаны). Высота затылка надъ верхниль краемь затылочнаго отверстія-- 3,5 см. 'Темянныя кости совер-

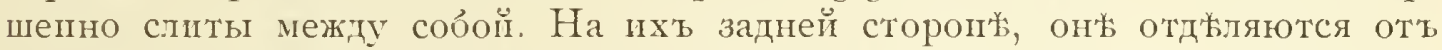
os interparietale (междутемянная кость) швомь болье рәзким, чьым шовь между темянны и височными костями. Шосльднія (височныя кости) вктиниваются между затылочнымъ гребнемъ и темянными костямп почти на самомь верху перепной коробки, гды бока затыпонаго гребня пере-

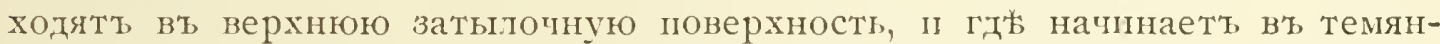

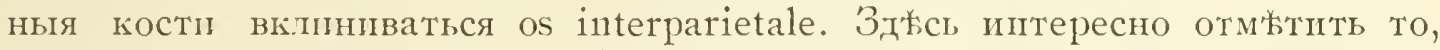
что часть petrosa (pars petrosa) - каменистая кость височной кости совершенно раздьлена швомъ отъ pars squamosa (собственно височнойчешуйчатой) кості. Pars petrosa-каменистая кость--вклинивается между pars squamosa височной костл іл затылочной узкою костью, ооразующей

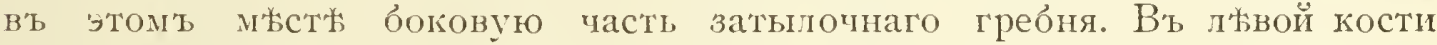
petrosa сохранилась бараóанная кость (os. tympanicum), представляющаяся труокой наружнаго уха. С` правой стороны барабанная кость отсутствуетъ, и вт глубин灰 черепной коробки видент костный лабирпнть внутренняго уха. Os petrosa- гаменистая кость только немного не доходить своимь верхиимь краем'ь до темянныхъ костей, чему мьшаеть чешуйчатая, соб́ственно височная кость (pars squamosa), которая иринимаеть

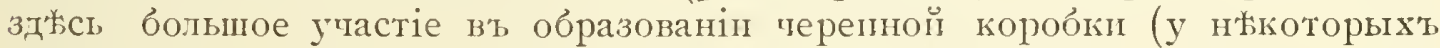
животных`ь эта кость только незнатительно участвуеть въ образованіи черепной коробки, являясь совершенно самостоятельной накладнойчешуйчатой костью, откуда и ея назвапіе). ЈІъвая височная (собственио -pars squamosa) сохранила свой сочленовный для нижией челюсти отростокъ-(processus zygomaticus). У правоц̆ же кости этот’ отросток' сохранился только наполовину. Соченовная поверхность льваяо (цьлаго) proc. zygomaticus дыя сочлененія съ нижней челюстю является в'ь виды слегка выпуклой, какт у всћхъ жвачныхт, округло-четырехугольной поверхностью, расположенной почти перпендикулярно к’ь осп черепа съь наклономь всей плоцадки нжсколько впередъ п сильнже внутрь. Темянцыя кости 'терега, имњющія посредины его 5,5 см. длины, соприкасаются съ

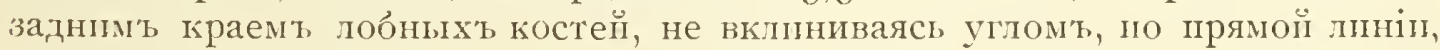
перпендикулярной продольной оси черена. По ихъ верху, съ обћихъ сто-

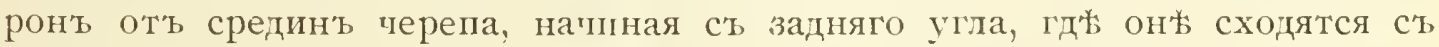
височной и затьлочной костями, проходять двы рызкія дугоооразныя скульптрныя линіи, расходящіяся затћм, у самыхъ лобныхт отростковъ

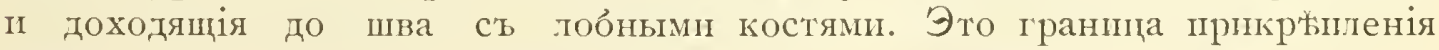
височныхъ мышць. Несросніяся лобныя кости им'ьют’ по ихъ поверх- 
пості от' темянныхъ, костей до пхъ передпих э обломаныхъ концовъ

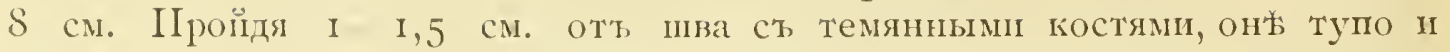

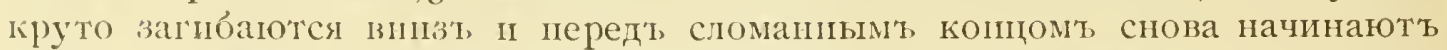

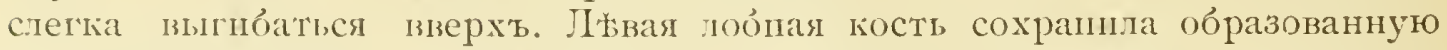

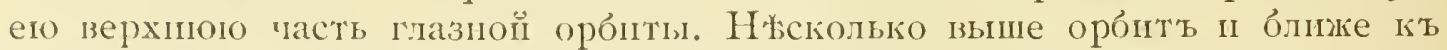
среднниому шву паходятся глуовокія падпиы съ рядомъ отверстій. Это сосудисто-первиыя ппадиы. Задие-паружный край каздой лобпой кости какт-разт, за орбптами п внше пхт сложень в'ь толстую складку, продолжанцуюся пверхт, п переходяцую в' лобиый отростокт-основаніе pora. Длппа повнихт отростковт I см. Напменьшее разстояніе между піпми по :оо́по-темяниому пву 2 см. Іравая лобная складка и лобный

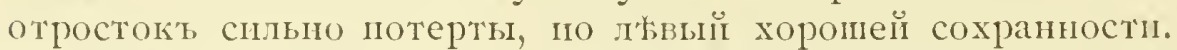

Изт костей, закрывающихт, терепную короо́ку сппзу, сохранплись хорошо почти всъ. Осповная затылогиая (basilare) кость, сохранплась и вошла въ образо-

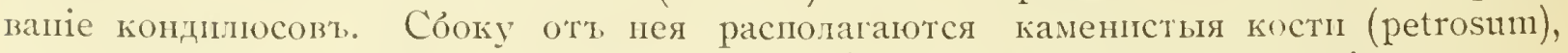

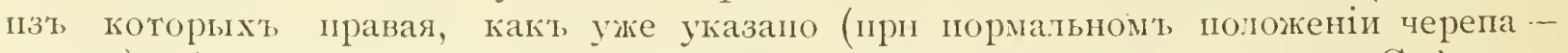
правая), обломана п открываеть раковину-лабнрипть внутренняго уха. Собственно основная кость (basisphaenoidenm) слплась свопмт заднпмъ краемт с'ь основной

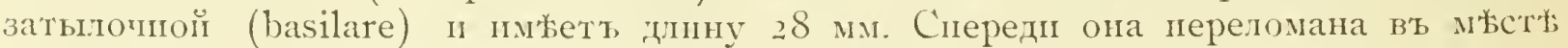

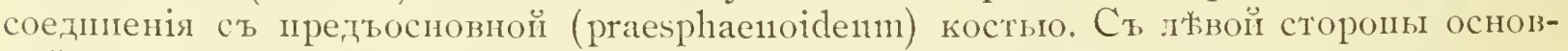

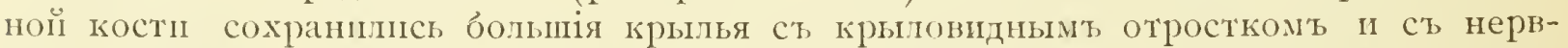
нымп (диумя) отверстіям. Эти крылья съ правої стороны обломаны п вдавлены

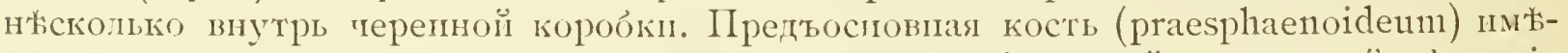
ет’т, хоропо раз̆нпюя малыя крылья, превосходящія своей величиной больнія крилья осиовной кости (basisphaenoideum). Наконец' передняя часть дна черепной коробки сохранила наполовиу внутрепнюю сторону р’ылтчатої (ethmoideum)

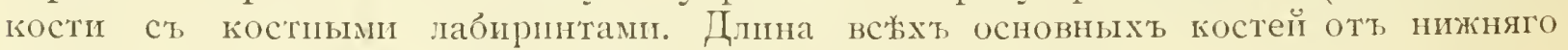
грая затылочнаго отверстія до ржнетчатої кості 65-7о мм.

Цетальне сравненіе этого перепа съ перепам олепеныхт, храняцихся въ Зоологичскомь Музељ Императорскаго Московскаго Университета, съ любезнаго разрншенія профессора Г. А. Кожевникова, которому и ириношу свою благодар-

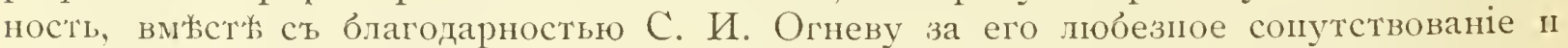
указаніе матеріаловъ Музея, даетъ несомпюниое указаніе па прпнадлежность этого

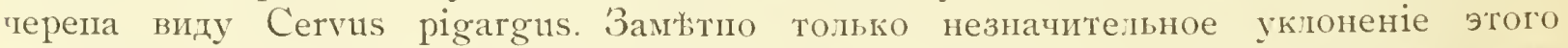

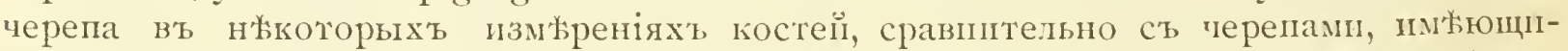
мися въ Зоологческомъ Музељ Императорскаго Московскаюо Универсптета (имъются 2 черепа Cervus pigargus изъ Минусинскаго округа по пнуровой кпиг S o I $388-8$ п S oo I 388 - I 5). Этп уклоненія касаются темянныхь п затылочныхъ костей. Длина темянныхъ костей экземиляровъ Зоологтескаго Музея

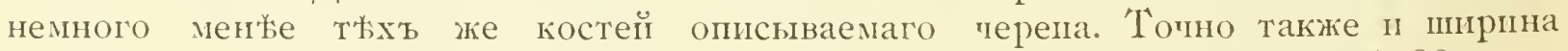
затылочиыхт гостей. Всльдствіе этого черепьь Красноярскаго музея А 88 - I 7

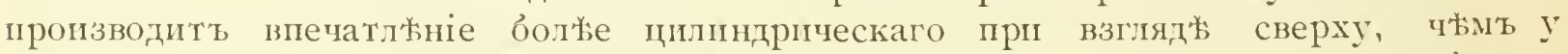
образцовъ Зоологическаго Музея, гды зам'тиа оолыная скатость череповъ въ області затылочнаго гребня. Наконец', указанная меньшая длина темяниыхь костей у

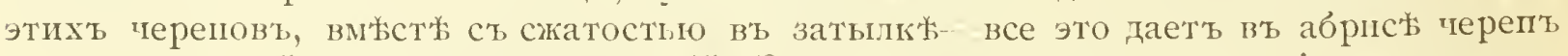
болюе округлый, тын цилипдрпгескій. Эти незпачительныя уклоненія, которыя не могутьь быть, какъ увидимъ ниже, результатомъ одното только различія въ воз-

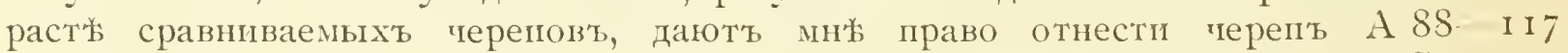
Красноярскаго музея къ Cervus pigargus же, но поставить его съ сf., т. е. Сеrvus c f. pigargus почті тождественным по формћ. Мжстонахокденіе черепа-доны с. Јадейскаго, окрестн. г. Красноярска.

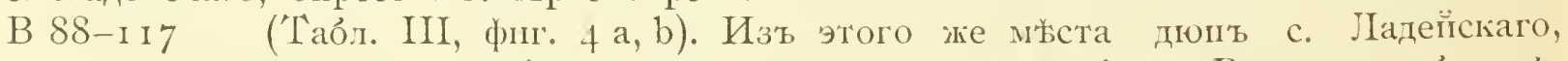

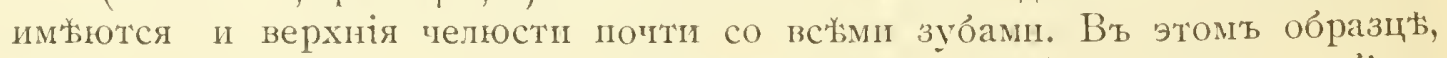

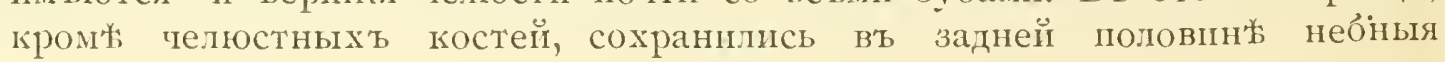




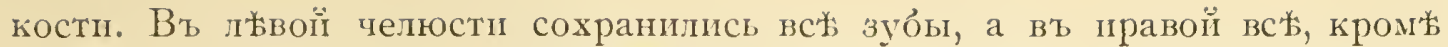

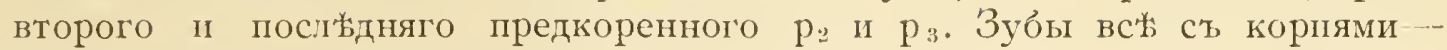
безъ постояннаго роста.

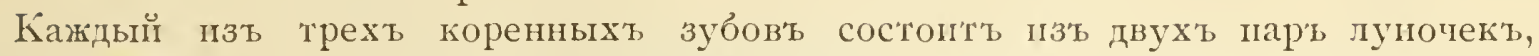
сильно сжатыхъ въ направленіи спередн-назадъ. Всльдствіе этой сжатости, зубы въ поперечном разризъъ являются почти квадратпыми, если даже не болье удлиненными въ поперечномъ напранленіп. Внутрениія стороны как' наружныхъ,

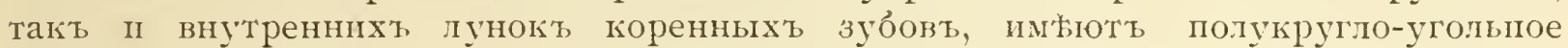

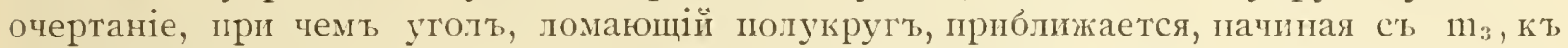
$\mathrm{m}_{1}$ все болфе въ передній уголь лунки, вытягивая, такъ сказать зубы въ діагональномъ направленіп. Всльдствіе этого выстраиванія каждаго зуба въ діагональ-

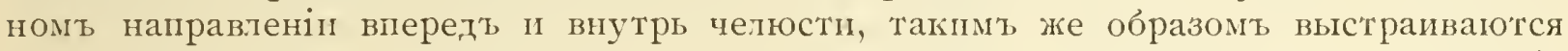
I междулуночныя, превращенныя въ угловатыя углубленія, долинки. Внутреннія луночкп каждаго зуо́а не сливаются свопми внутреннии углами прямо, а каждый изт передних угловъ внутренней задней лунки образуеть небольшую складочку, направленную впередъ и внутрь и въ пмйюцейся степенп стиранія еще не соедпняющую пунки п пропзодицую впечатльніе, что соеднненіе лунокъ въ этомъ

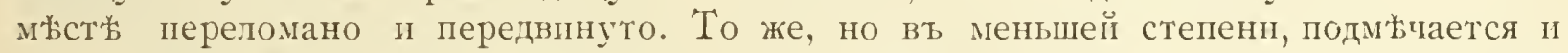
во внутреннихъ углахъ наружныхъ лунокъ. Если внутреннія луниц имлли полукругло-угольное очертаніе, то наружныя имсноть очертаніе совершенно треугольное, съ верпиной, обращенной внутрь и слегка впередъ челюсти. При этомъ основаніе треугольника у заднихъ наружныхъ лунокъ также переломано посрединъ подъ угломъ, обраценнымъ также внутрь. Переднія наружныя лунки всъхъ зубовъ, отличаются от’ заднихь т点мъ, что ихъ наружный бокъ, также слегка вдающійся внутрь, имъетъ посрединй небольшую складочку, обращенную наружу. Во всбхъ коренныхъ нужно подмытпть ръзкость угловъ пунокъ и присутствіе маленькаго

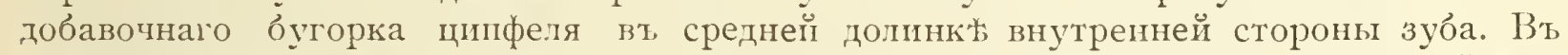
первомь коренномь $\left(\mathrm{m}_{1}\right)$ цицфель находптся въ началь стиранія. Каждый нљь предкоренныхъ зуоовъ состогт⿱ пъъ одной пары пунокъ болье массивныхъ, гйъ пары лунокъ коренныхъ зубовъ. Тутъ тоже сохраняется хараптеръ округлой внутренней лунй п угловатой, всльддствіе складки эмали наружной сторонынаружной. Эта складка эмали находится въ передней части луночки, и значительно болье ръзко выльляется на посльднемъ предкоренномъ (рз) зубъ. Между прочимь на обоихъ $p_{1}$ (правомъ п львомъ) вблизи задняго угла внутренней пунки замьтны незначительныя углубленія. На львомъ $p_{1}$ хорошо замю́тно, что это эмалевое углубленіе, п сльғов. является дномъ стершагося эмалеваго углубленія или залива между складкамп, о формж котораго судить нельзя. Интересно также п то, тто

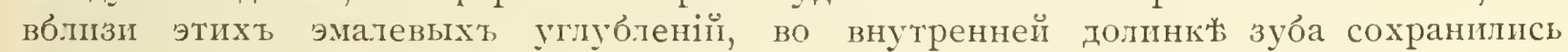
нрзначительныя складки эмали, входящія внутрь междулуночной долинии. Несо-

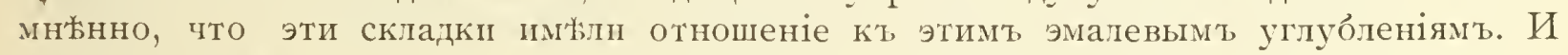
это подтверждается тймћ, что зависимость пхъ и сейчасъ легко устанавливается:--

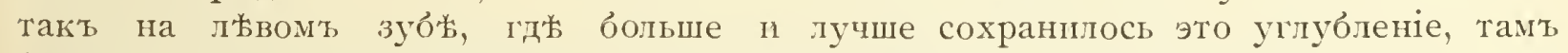
больше и лушше выражела и эта складка. Длина трехъ львыхъ коренныхъ по прямой линіи 39 мм. Қлина трехъ львыхъ предкоренныхъ 3 г мм. Тотчасъ за $\mathrm{p}_{3}$ и выше его, на 5 мм. выше края челюсти, находится верхне-челюстное сосудистое отверстіе. Внутри правой челюсти виденъ его трубчатый, сплюснутый ходт, проходящій по внутреннему граю зубного ряда.

Эта челюсть была сравнена съ челюстями, именшимпся при черепахъ Зоологпнскаго Музея Императорскаго Московскаго Упиверситета. Это т我же черепа Cervus pigargus, съ которымп быль сравниваемъ п оппсаный выне черепь. Изъ

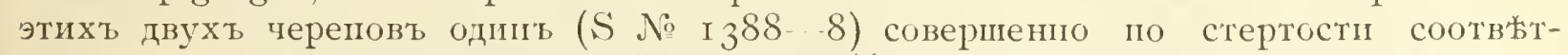

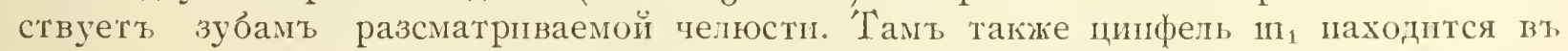
началь стиранія. Незначигельныя только уклопенія въ характерь луночекь зубовъ также дають право поставить эту челюсть подт пменемь Cегvus cf. pigargus. 


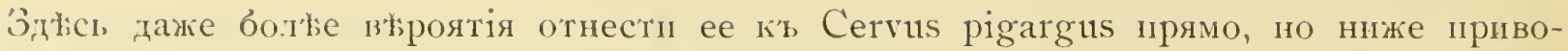
димыя сооораженія говорять скорте за первое.

Одно и то же мъстонахожденіе этой челюсти сы, описаннымт выне черепом

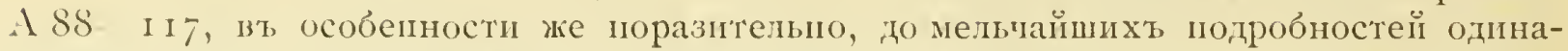
говая стенеп, сохранности даютљ право предполагать, что эти два обломка (черепь

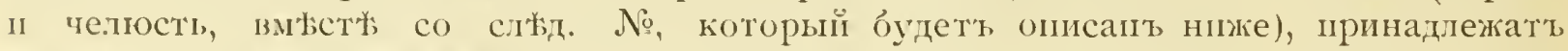
одному ІІ тому же индинцду.

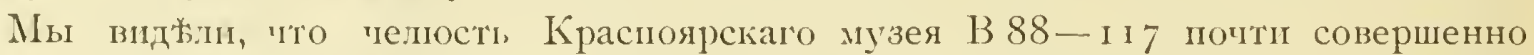

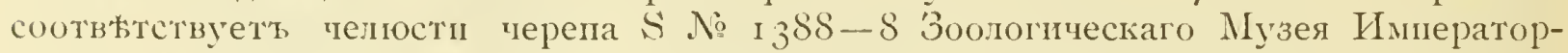
скаго Московскаго Упиверситета. Кт сожальию, у этого перепа отсутствуть

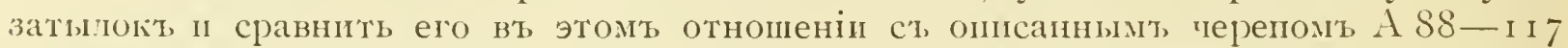
погробно пе представилось нозможным. Но характерная сжатость въ области затылка у другого черепа, большая округенность терепной коробки замтиается и

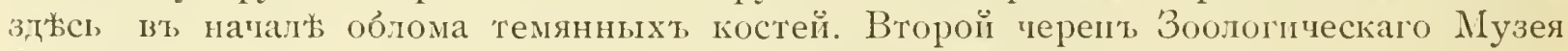
S oo I 388 -- I 5 , по зубамт, моложе описываемой челюсти.

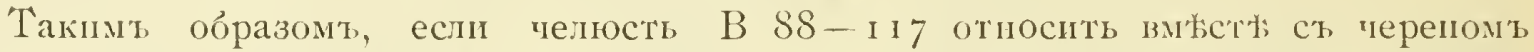

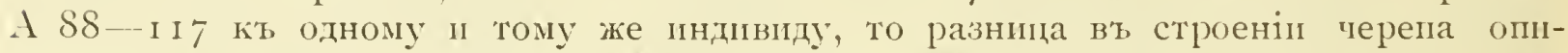
сапнаг и черепов Зоолог. Музея Императ. Моск. Универсптета ни въ коемъ

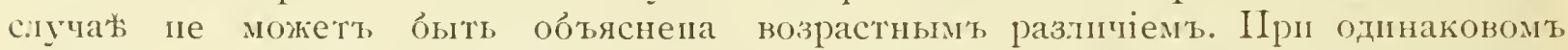

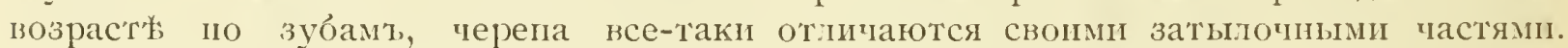

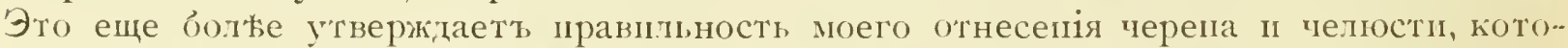
рую я спита принадлежащей тому же ипдивцд, кт, Cervus cf. pigargus.

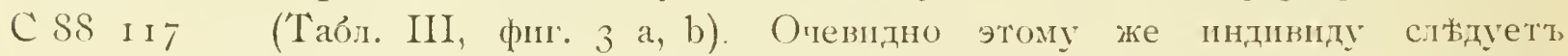
отнести, какъ по его сохраниости, такт и по соотвытствію затылочнымт мыщелкамъ Atlas ( - п̈ пейный позвонокт), пайдепный вт, томъ же мћсть. Его очень тонкія крылья обтомапы п судить о его форм's сверху пли снизу не представляется возможнымт. На спнной поверхности спиьно выражент бугорь, соотвытствующйї остистому отростку (processus spinosus superior). 'Гжло позвонка подт крыльями (proc. transversus) съ боковт сильно сжатое, перовное. Видт передней соленовиой поверхности равнобедренно-трапецоидный, с’ мепьлей стороной пнизу. Напо́ольиая ширина этой поверхности 44 мм. Высота--22 мм. Сильные выгающеся оугры, обхватывающіе снизу затылоные кондилюсы, пироко разстанлены. Между

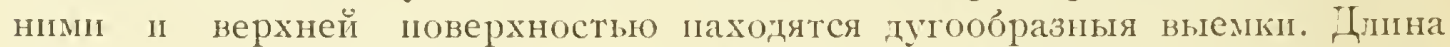
тьла позвонка-(нпжн. пов.) $3^{\mathrm{I}}$ мм. Дина спиной дугі (верхн. пов.) 28 мм. Задняя сочленовная поверхность со 2-мъ шейным позвонкомь едва вогнутая, почти плоская, треугольнаго очертанія. Вндъ мозгового отверстія спереди - полерепно-элисовидное, правилыое вверху п съ угломт, ннизу. Видь этого отверстія сзади соверненно круглый.

Описанный позвонокь совершенно соотвътствуеть и подходить къ затылочпымь мыщелкамь терепа А 88 - I 17.

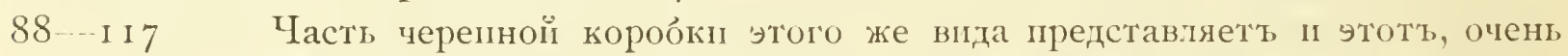
плохой сохранности, обломокт. Это часть темянной кості п тасть лооныхъ съ обтертыми роговыми лобными отростками. Найден'ъ въ тыхъ же дюнахъ с. Ладейскаго.

\section{C e r v u s s p.}

Лжвая пястиая кость (метакариљ). Вт впду крайней потертости и поломанности этого остатка явлется очень затруднительным назвать его болье точно, чюмь Cervus sp. Можно только ст, увжренностью сказать, что онъ пе принадлежить Cervus tarandus, одинаковому съ нимь по величинъ. Биріоса-лжвый берегт р. Енисея. 


\section{R e s u m é.}

Der hier beschriebene T'eil der paläontologischen Kollektion aus dem Museum der Stadt Krasnojarsk, Gouv. Jenissejsk, stellt fossile Reste ron Hirschen dar.

Diese Gruppe ist in der vorliegenden Kollektion vertreten durch Reste von Geweihen des Cervus elaphus fossilis Fisch. (Cervus canadensis var. Maral Tschersky), durch den ersten Halswirbel, Bruchstücke von Geweilien und des I'nterkiefers (Taf. III, Fig. Ia, b, c) von Cervus euricerus Aldr., Schädelstïcke vo11 Cervus cf. pigargus (Capreolus pigargus Pall.) ('Taf. III, Fig. 2a, b, 4a, b), durch Kinochen der Gliedmassen, Fragmente von Geweihen, Kiefer und Schädel von Cervus tarandus fossil. Ow. (Taf. I, Fig. I, 2, 3, 4a, b, c, 5, 6a, b; Taf. II, Fig. I a, b, 2, 3, 4a, b, c, d).

Unter den Knochen der letzten Art ist eine Reihe von Kiefern bemerkenswert (Taf. I, Fig. 3, 4a, b, c, 5), welche die Veränderung der Zähne mit vorschreitenden Alter verfolgen lässt, angefangen von einem Kiefer nit wohlerhaltenen Milchzähnen und noch nicht durchgebrochenen $m_{3}$ (Taf. I, Fig. 3) bis zu dem ältesten, auf 'Taf. I, Fig. 5, abgebildeten Kiefer.

Interessant ist in dieser Hinsicht auch die hier beschriebene Reihe von Schädeln (Taf. I, Fig. 6a, b; Taf. II, Fig. Ia, b, 2, 3, 4a, b, c. d). Vom juingsten (Taf. I, Fig. 6a, b) zum ältesten (Taf. II, Fig. 4a, b, c, d) rorschreitend rerfolgt man das Zurücktreten des Hinterhauptes unter den Schädel und eine Veränderung der Scheitelknochen mit dem Alter; letztere werden dabei oben am Schädel schmäler, während ihre Ausbiegungen auf den Seitenteilen des Schädels kräftige Falten bilden, welche die Geweihe von aussen stützen.

Diese Veränderungen der Scheitelknochen sind wohl ausschliesslich auf mechanische Ursachen zurückzuführen: der Druck der wachsenden Geweihe, auf die Stirnbeine sich übertragend, bewirkt eine Verstärkung und Ausbreitung derselben, wodurch die Scheitelbeine oben am Schädel zum 'Teil verdrängt werden. Der gleiche Druck bewirkt anch, dass die Scheitelknochen starke Falten bilden, die die Geweilie stiitzen. Hier konnten sich die Scheitelknochen nicht verkleinern, wie es oben der Fall ist, da sonst den Geweihen die Stiitze entzogen würde, welche diese Falten ilnnen bieten.

Alle diese fossilen Reste stammen zum grösten Teil aus den Umgegenden der Stadt Krasnojarsk, und nur vereinzelte sind in entlegeneren Gegenden aufgefunden, so z. B. ein Gewieh ron Cerv. enricerus und einige Geweihe ron Cerv. elaphus im Kreise Minussinsk des Gouv. Jenissejsk, der Kiefer ron Cerv. euricerus -in den Umgegenden der Stadt Kansk, Gouv. Jenissejsk, und der Schädel ron Cerv. tarandus № I2-- I im Kreise Turuchansk desselben Gouvernements. 


\title{
ОБЪЯССЕНIE ТАБЛИЧЪ.
}

\author{
Табл. I.
}

Фиг. 1. Правый метакарпъ Cervus tarandus fossilis. № go. Видъ сзади. Изъ Бнрюсинской пещерь, въ 50--6о верстахт, отт, гор. Красноярска. Около $3 / 7$ натуральн. велгг.

2.--Правый метакарпъ Cervus tarandus fossilis. № 88 - I3. Видъ спереди. Кирничн. сарап за военнымт городкомъ. ${ }^{4} / 9$ натуральн. велпч.

3.--Правая нижняя гелюсть Cervus tarandus fossilis съ молочнымп зубами. oo $8 S-5$. Жевательная поверхность зубовт. Кирпичн. сарап за военн. городкомъ. $1 / 2$ натур. велич.

4 a, b, c.-- ПІравая нижняя челюсть Cervus tarandus fossilis. № $90--8$. Изъ культурнато слоя у переселенческаго пункта противъ гор. Красноярска.

4 а. - Кевательная поверхность зуо̉ов'ь. 1/2 натур. велич.

4b. - Внутренняя сторона челюсти. ${ }^{1 / 2}$ натур. велич.

4 с. - Наружная сторона челюстп. 1/2 натур. велич.

5.- ЛГжвая нижняя челюсть Cervus tarandus fossilis. № 88 г26. Жевательная поверхность зубовъ. Кирпиные сарап за военнымъ городкомъ. 1/2 натуральн. велич.

6 a, b. - Чepeпъ Cervus tarandus fossilis. № $88-2$. Кпрпичные сарап за военнымъ городкомъ. $1 / 2$ натур. велич.

6 а. - Видъ герепа с'ъ затнлка. $1 / 2$ натур. велич.

6 b.--Видъ черепа сверху. 1/2 натур. велпч. 
Поствтрет, мпскопит. Краспоярск. Музея.
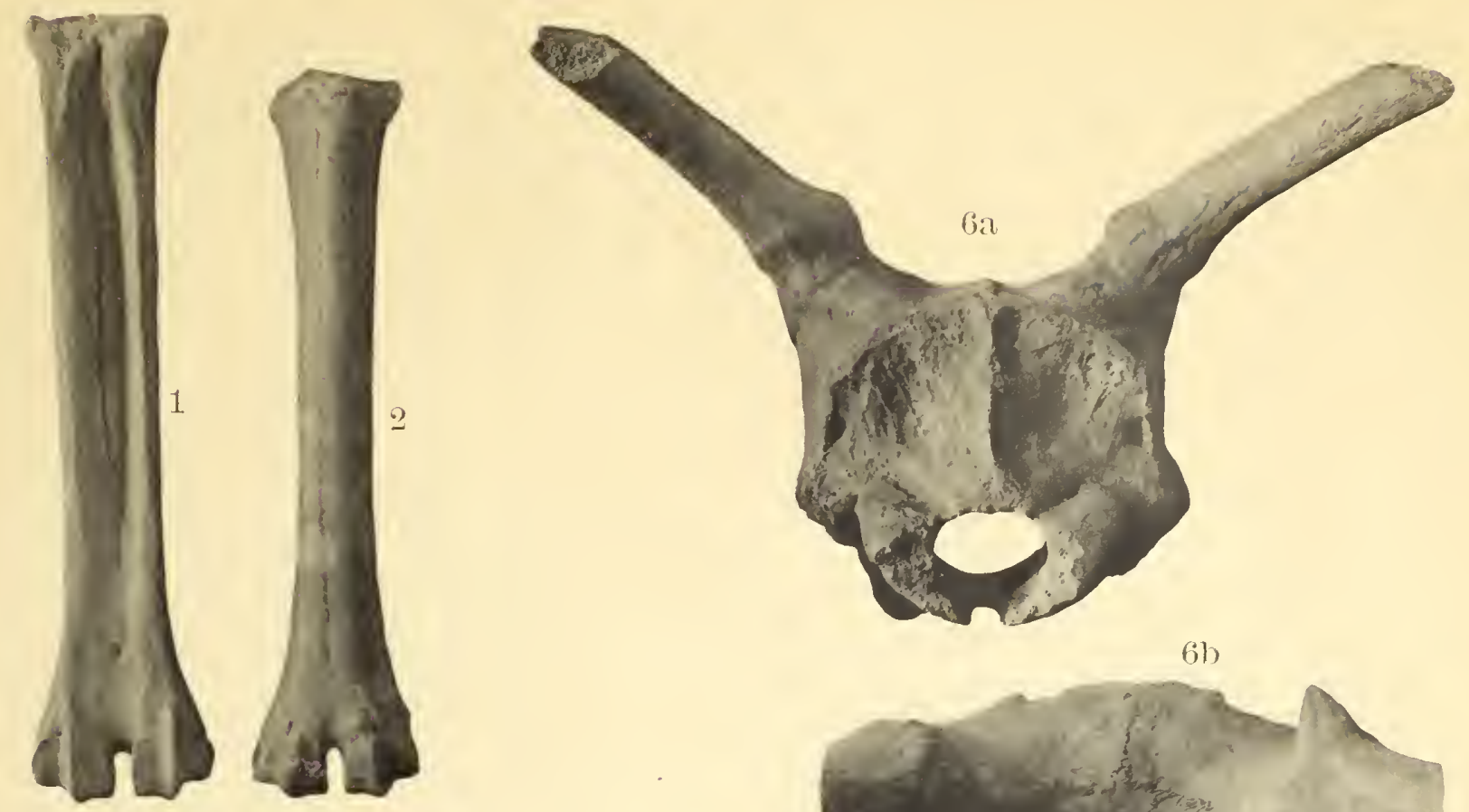

61
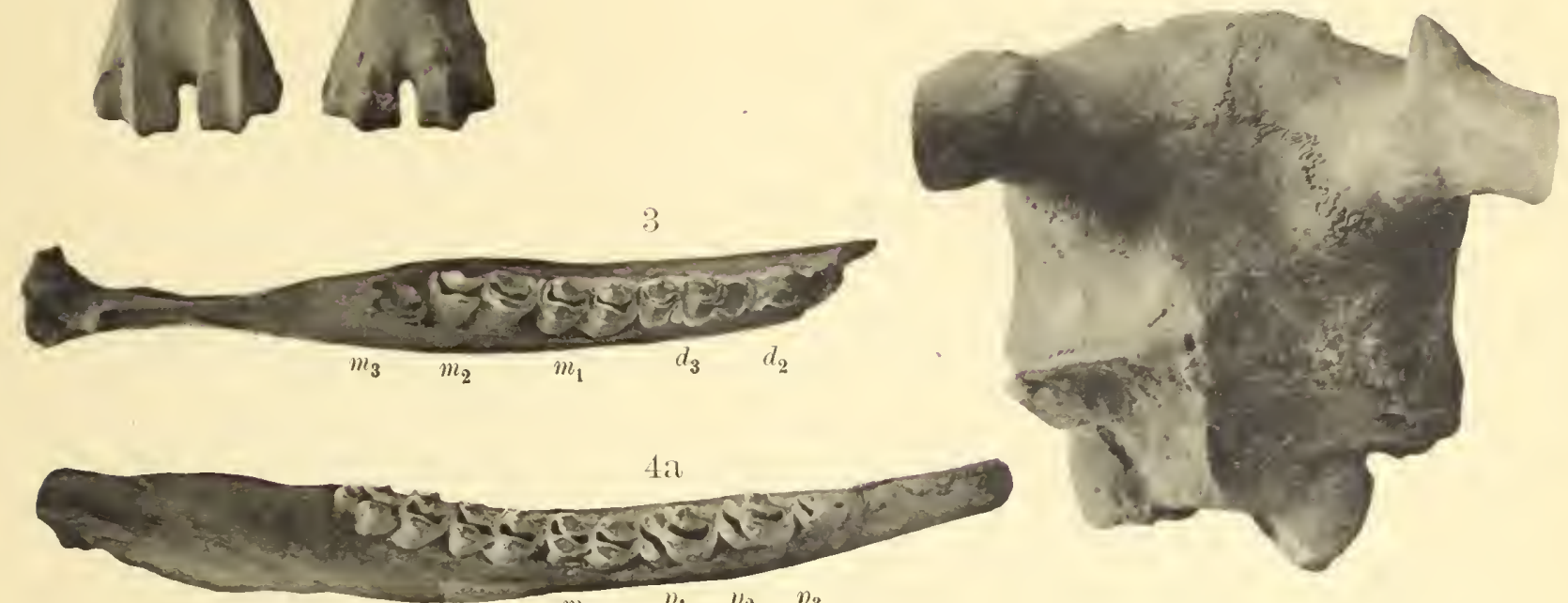

$4 a$

$1235=25 x^{2}$

5
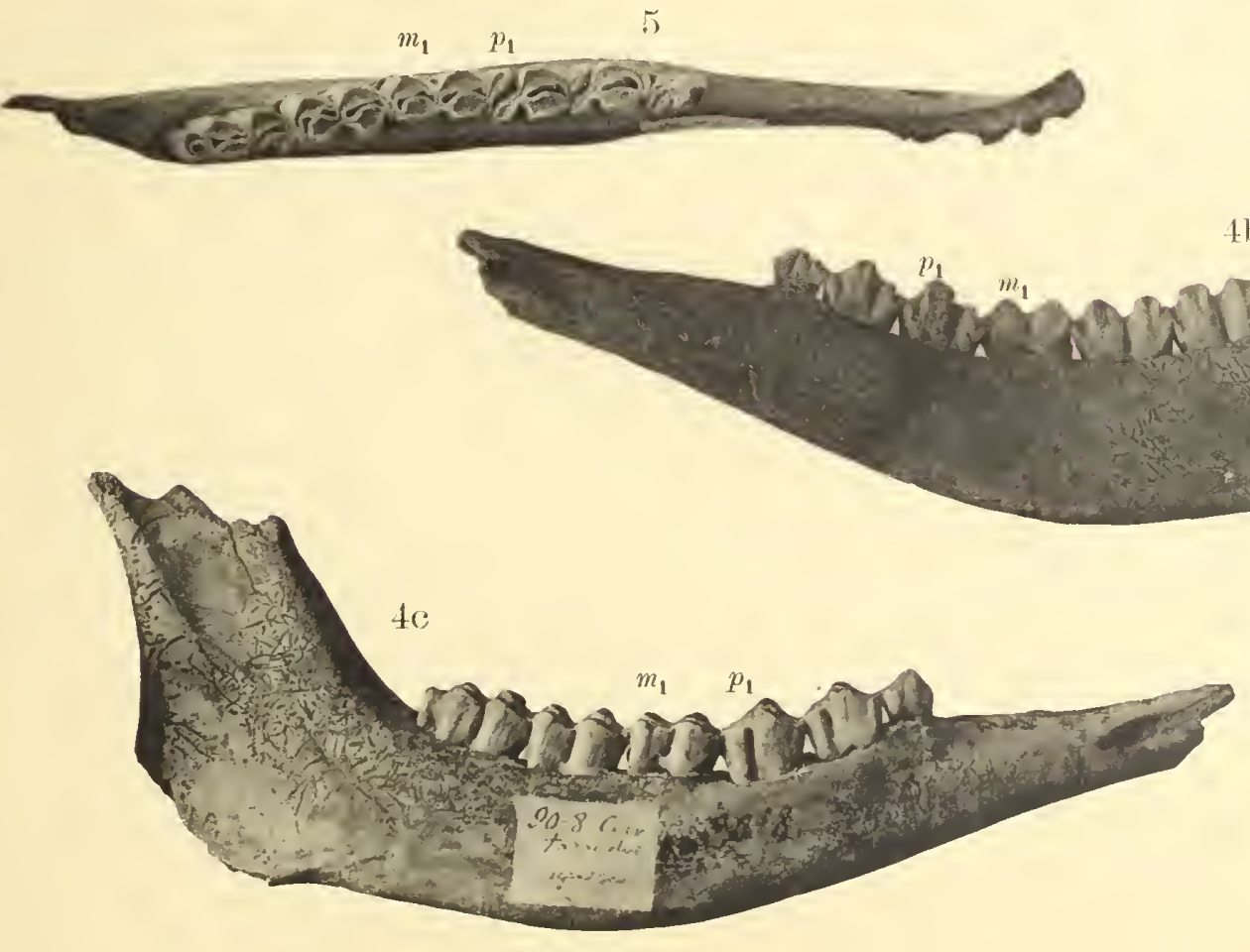

4h.

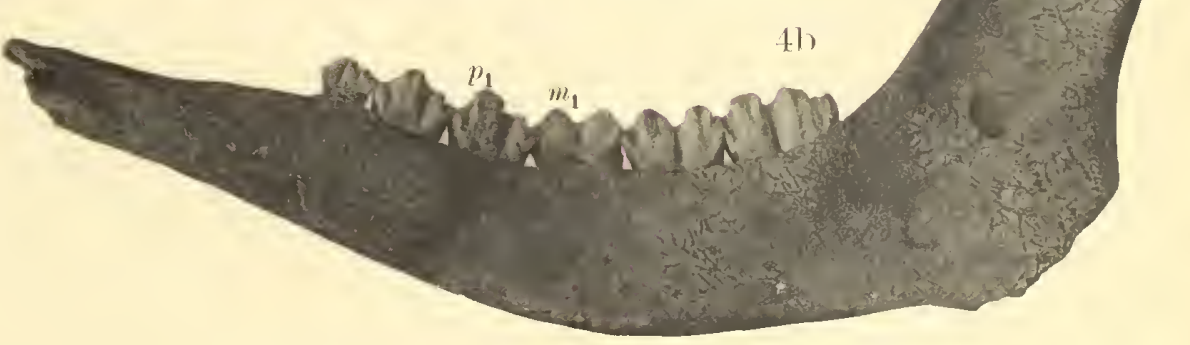






\section{Табл. II.}

Фиг.1 a, b. - Черепъ Cervus tarandus fossilis. № 88 - 8. Военный городокъ, окр. rop. Красноярска.

1 а. - Видъ праваго бока черепа.

1 b.-- Видт черепа сверху.

2. Видъ сверху черепа Cervus tarandus fossilis. № 88 -I27. Кирпичн. сараи за военнымъ городкомъ.

3.- Видт л'вой стороны черепа Cervus tarandus fossilis. № $88-3$. Логт кирпичныхъ сараевъ за военным' городком'ъ.

4 a, b, c, d.- Черепт Cervus tarandus fossilis. № I 2- I. Тазовскій ${ }^{\circ}$ Носъ, Туруханскаго края.

4 а. - Видъ правой стороны черепа.

4 b. - Видъ затылка.

4 c.--Видт нижней стороны черепа.

4 d.-Видъ черепа сверху.

Буква P указываетъ боковые загибы темянныхт (Parietalia) костей.

Всъ фигуры этой таблицы даны вт ${ }^{1 / 2}$ натур. велич. 

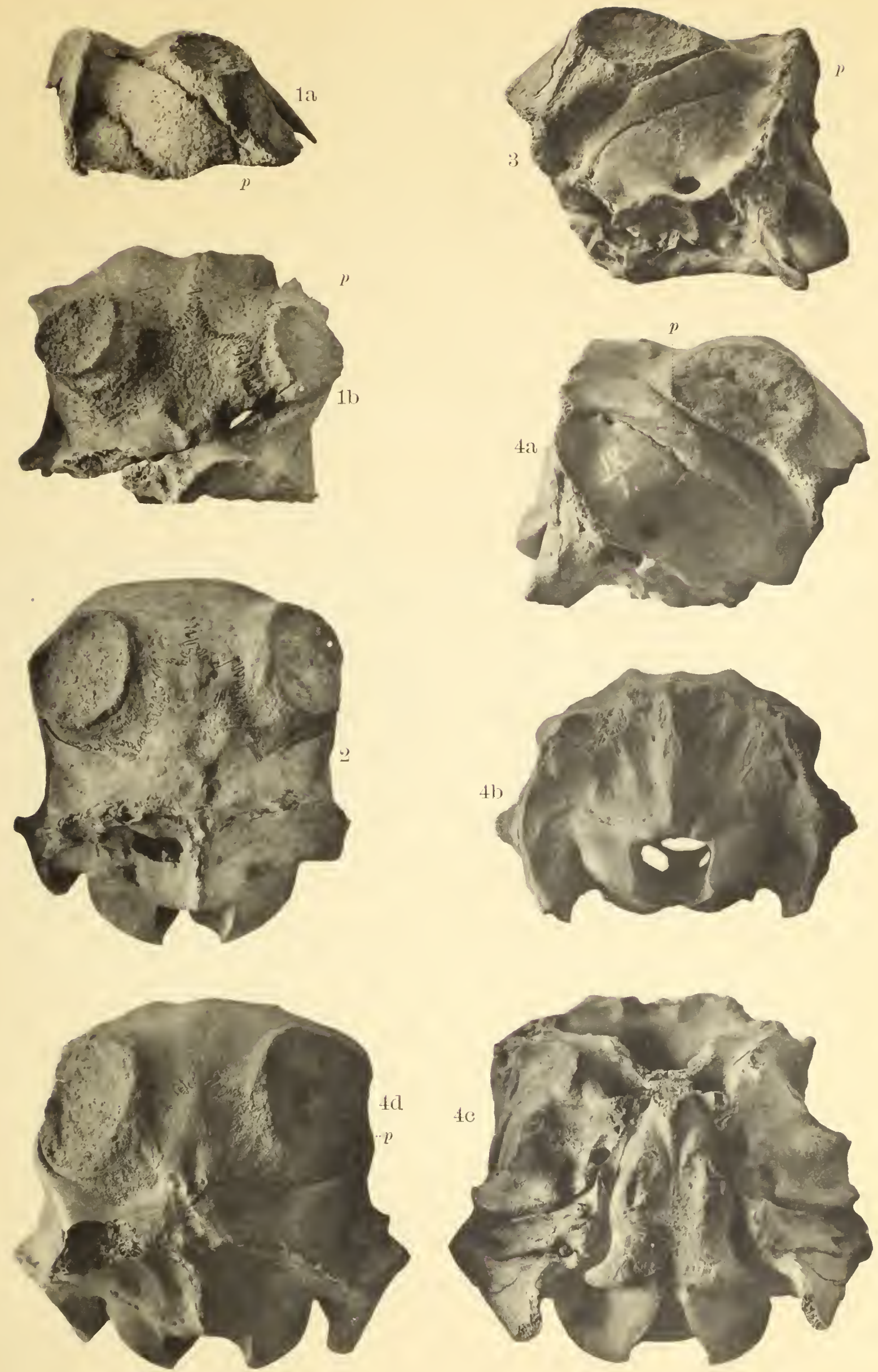



\section{Табп. III.}

Фиг. 1 a, b, с.—Праная нпжняя челюсть Cervus euricerus. № 9 I I. Изъ галечныхъ отложеній окрестностей гор. Канска, Енисейской губ.

1 а.-Видъ жевательпй поверхности.

1 b.-Наружный видъ челюсти.

1 с.-Внутренній видъ телюсти.

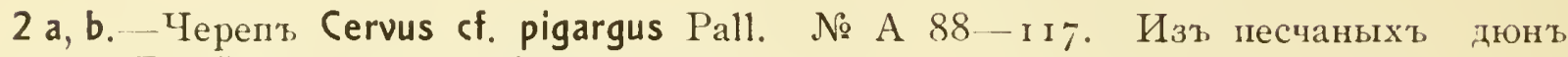
окр. с. Јадейскаго, близъ Красноярска.

2 а.--Видьь черепа сверху.

2 b.- Видъ лювой стороны херепа.

3 a, b.-Atlas - г -й шейный позвонокъ- Cervus of. pigargus. № C 88-- г т. Изъ дюнь с. Ладейскаго, окр. г. Красноярска.

3 а. - Нижняя поверхность позвонка.

3 b.--Передняя солленовная поверхность позвонка.

4 a,b.-Верхнія челюсти Cervus of. pigargus Pall. № B 88- і г . Изъ дюнъ с. Јадейскаго, окр. г. Красноярска.

4 а. - Жевательная поверхность зубовъ.

4 b. Видъ л出вой стороны челюсти.

Буква С вт фиг. га, I b указываетъ ципфелг, в’ долинкахъ зуобовъ.

Bсғ фигуры этой таблицы даны въ $1 / 2$ натур. велич. 

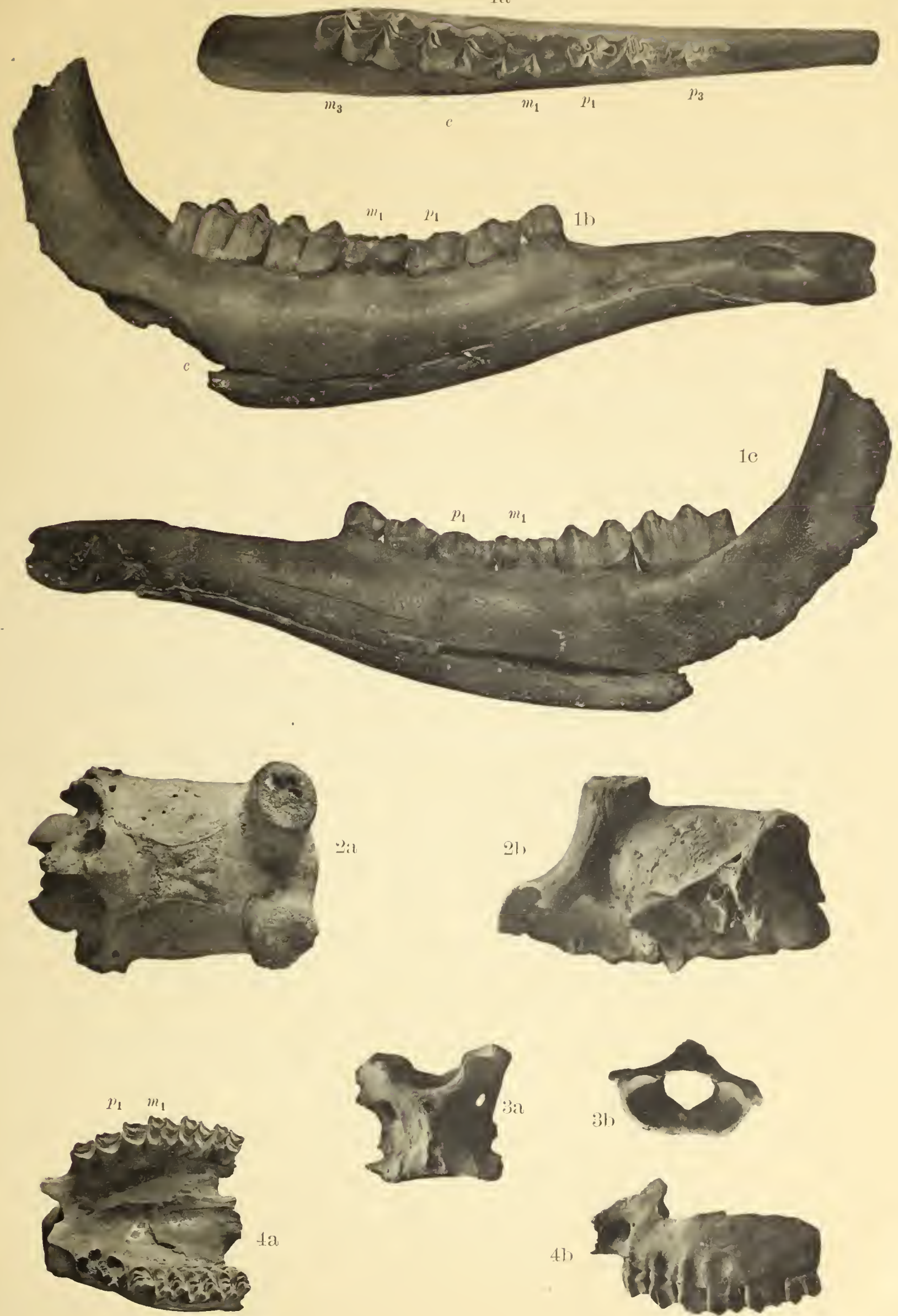

$4 h$

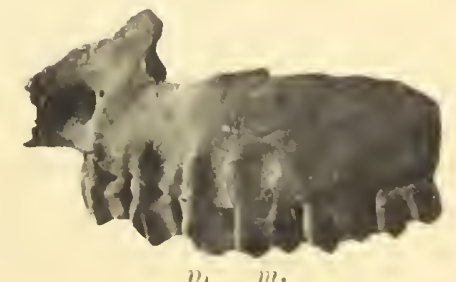





\section{Н 3 Д А Н І Я}

\section{Красноярскаго Подъотдъла Императорсқаго Руссқаго Географическаго Общества.}

Изв ьСтІя. Т. І, в. 1. Протоколъ торжественнаго публичнаго засьданія 28 января 1901 г.

T. 1, в. 2. Іротоколы засьданій отъ 13-го ноября по 4-е мая 1904 года.

T. I, в. 3. Протоколы засьданій Распорядительнаго Комитета за вторую половипу 1901 г. Е. Яковлевъ. Этнографическія замђтка о сойотахъ-урянхайцахъ. А. Вознесенскій. Записки объ организаціи физико-географическихъ изсльдованій Красноярскимъ Подъотдђломъ И. Р. Г. О.

Т.І, в. 4. В. Ю. Григорьевъ. О значеніи мыстныхъ музеевъ вообще и Минусинскаго въ частности. С. В. Востротинъ. Адольфъ Эрихъ Норденшильдъ, біографическій очеркъ. Я. А. Макеровъ. Иванъ Васильевичъ Мушкетовъ, біографическій очеркъ. А. В. Адріановъ. Нахожденіе костей мамонта и друг. допотопныхъ животныхъ въ окрестностяхъ села Сухо-Бузимскаго. Приложенія. 1) Программа для собиранія свыдыній о деревенскомъ быть. 2) Записка Е. Г. ІІІольпъ о статистическомъ изсльдованіи о числь лиць, удовлетворяющихъ цензу, установленному закономъ для присяжныхъ засБдателей. 3) Инструкція для руководства членамъ библіографической комиссіи. 4) Протоколы засьданій съ 1-го января по 27-е мая 1902 г. 5) Отчетъ за 1901 г.

Т.І, в. 5. Проф. А. М. Зайцевъ. Въ поискахъ за руднымъ золотомъ. П. Е. Островскихъ. О положеніи женщины у инородцевъ Туруханскаго края. В. Ю. Григорьевъ. Замђтки объ Ивановскомъ свекло-сахарномъ заводь г-жи Гусевой. П. Островскихъ. Мангазейская книга. Протоколы засьданій за вторую половину 1902 г.

Т.І, в. 6. В. Ю. Григорьевъ. Красноярское Географическое Об-во на исходь трехъ льтъ своего существованія. Онъ-же. С. Каратузское 'и проживающее въ немъ постороннее населеніе. П. Островскихъ. Пођздка на озеро Ессей. Онъ-же. Къ маршрутной картђ оз. Ессей. В. И. Анучинъ. Матеріалы къ областному словарю сибирскаго нарьчія. Я. П. Прейнъ. Дополнительныя свђдьнія о мЂстонахожденіи липы въ окрестностяхъ Красноярска. Онъ-же. Списокъ растеній, собранныхъ льтомъ 1902 года въ долинь р. Хормы, Бирюсинской золотоносной системы. Онъ-же. Списокъ растеній, собранныхъ въ окрестностяхъ с. Алтатъ, Ачинскаго ућзда, Енисейской губ. В. И. Анучинъ. Работы по обсльдованію волостныхъ и церковныхъ архивовъ Енис. губ. А. Кауфманъ. Ньмецкій экономистъ о колонизаціи Сибири.

Т. ІІ, в. 1.В. Ю. Григорьевъ. Николай Васильевичъ Латкинъ (некрологъ). А. В. Адріановъ. Викторъ Александровичъ Даниловъ (некрологъ). В. Ю. Григорьевъ. Владимиръ Васильевичъ Моторинъ (некрологъ). А. В. Адріановъ. Памяти Н. М. Мартьянова. Лаппо Д. Е. Преступленія и наказанія по стелному праву сибирскихъ кочевыхъ инородщевъ (Минусинскіе татары). $\vec{A}$. И. Кытмановъ. Къ флор' сосудистыхъ растеній рьки Ангары.

Т. II, в. 2. Протоколы за 1904 годъ. Отчетъ за 1904 г. Протоколы за 1905 годъ. Отчетъ за 1905 г.

Т. II, в. 3-4. Краткій обзоръ Красноярскаго Городского Музея, состоящаго въ завђдываніи Красноярскаго Подъотдђла И. Р. Географическаго Об-ва. П. Червинскій. Изсльдованіе нђкоторыхъ породъ и минераловъ Минусинскаго округа, Енисейской губ. Проф. А. М. Никольскій. Матеріалъ 
къ герпетологіи Енисейской губ. Н. М. Ядринцевъ. Этнографическій альбомъ сибирской деревни. А. Я. Тугариновъ. Въ низовьяхъ Енисея. Предварительшый отчеть о пођздкь въ Туруханскій край льтомъ 1907 года.

Т. II, в. 5. Хейнъ И. А. Дневникъ поисковой экспедиціи, снаряженной Н. В. Асташевымъ въ спстему р. Нижией Тунгузки, съ предисловіемъ и подъ редакцісй А. В. Адріанова. Протоколь торжественнаго засъданія 12-го февраля 1909 г. въ день 20-льтія Красноярскаго Музея.

Т. II, в. 6. А. Ермолаевъ. Феиологическія наблюденія въ Енисейской губерніи. М. В. Красноженова. Изъ народныхъ обычаевъ крестьянъ д. Покровки. Н. А. Козловъ. Алфавитный указатель мъстностей Енисейской губерніи съ полезными ископаемыми. Н. С. Федоровъ. Фенологическія наблюденія въ Енисейской губ. за льто-осень 1910 г.

ЗАПИСКИ ПО ГЕОГРАФІИ. Т. І, в. 1. В. А. Ошурковъ. Отчегъ о пођздкъ, совершенной льтомъ 1902 г. въ Западные Саяны и западную часть хребта Таңну-Ола.

Т. I, В. 2-4. А. Я. Тугариновъ и С. А..Бутурлинъ. Матефіалы по птицамъ Енисейской губерніи.

ЗАПИСКИ ПО эТНОГРАФІИ. Т. І, в. 1. Русскія сказки и пъсни въ Сибири и друг. матеріалы.

Т. І, в. 2. К. И. Горощенко. Матеріалы по антропологіи Сибири.

T. I, в. 3. Русскія и инородческія сказки Енисейской и Томской губерній.

ЗАПисКИ ПО СТАТИстиКь. Т. І, в. 1. В. Ю. Григорьевъ. Перемъны въ условіяхъ экономической жизни населенія Снбири.

ЗАПИСКИ ПО МЕТЕОРОЛОГІИ. Т. І, в. 1. Наблюденія метеорологическихъ станцій Енисейской губ. за 1901 годъ.

T. I, в. 2. Тоже за 1902 годъ.

T.I, в. 3. Тоже за 1903 годъ. В. Б. Шостаковичъ. Вскрытіе и замерзаніе ръкъ въ 1903 году.

Протоколъ публичнаго засьданія 27-го марта 1911 года.

Отчеты за $1907-1910$ г.г.

ОПИСАНІЕ КОЛЛЕКЦІЙ КРАСНОЯРСКАГО МУЗЕЯ.

Отдђлъ Палеонтологическій, В. 1. А. Соболевъ. Посльтретичныя млекопитающія. А. Олени. Съ 3 таблицами. Цъна 60 коп.

Отдьлъ Археологическій, в. I. А. Ермолаевъ. Ншимская коллекція, Сэ 8 таблицами. Цъна 85 коп.

1

Отдъльныя изданія:

Краткій обзоръ Красноярскаго Музея, цъна 15 коп.

Программа для собиранія свђдъній о деревенскомъ быть (раздаются безплатно).

Скпадъи продажа изданій-въ гом ъщеніи Музея.

(Старобазарная прощадь). 
Pamphlet

Binder

Gaylord Bros.

yracuse, N. Y

PAT. JAN 21, 1908 
